\title{
Screening of Novel Laccase Producers-Isolation and Characterization of Cold-Adapted Laccase from Kabatiella bupleuri G3 Capable of Synthetic Dye Decolorization
}

\author{
Katarzyna M. Wiśniewska, Aleksandra Twarda-Clapa and Aneta M. Białkowska * \\ Institute of Molecular and Industrial Biotechnology, Lodz University of Technology, Stefanowskiego 4/10, \\ 90-924 Łódź, Poland; kma.wisniewska@gmail.com (K.M.W.); aleksandra.twarda-clapa@p.lodz.pl (A.T.-C.) \\ * Correspondence: aneta.bialkowska@p.lodz.pl
}

Citation: Wiśniewska, K.M.;

Twarda-Clapa, A.; Białkowska, A.M. Screening of Novel Laccase

Producers-Isolation and

Characterization of Cold-Adapted

Laccase from Kabatiella bupleuri G3

Capable of Synthetic Dye

Decolorization. Biomolecules 2021, 11 828. https://doi.org/10.3390/biom 11060828

Academic Editor: Vladimir N. Uversky

Received: 7 May 2021

Accepted: 30 May 2021

Published: 2 June 2021

Publisher's Note: MDPI stays neutral with regard to jurisdictional claims in published maps and institutional affiliations.

Copyright: (c) 2021 by the authors. Licensee MDPI, Basel, Switzerland. This article is an open access article distributed under the terms and conditions of the Creative Commons Attribution (CC BY) license (https:/ / creativecommons.org/licenses/by/ $4.0 /)$.

\begin{abstract}
Psychrophilic laccases catalyzing the bond formation in mild, environmentally friendly conditions are one of the biocatalysts at the focus of green chemistry. Screening of 41 cold-adapted strains of yeast and yeast-like fungi revealed a new laccase-producing strain, which was identified as Kabatiella bupleuri G3 IBMiP according to the morphological characteristics and analysis of sequences of the D1/D2 regions of 26S rDNA domain and the ITS1-5,8S-ITS2 region. The extracellular activity of laccase in reaction with 2,2'-azino-bis(3-ethylbenzothiazoline-6-sulfonic acid) (ABTS) at the optimal $\mathrm{pH} 3.5$ was $215 \mathrm{U} / \mathrm{L}$ after 15 days of growth in a medium with waste material and $126 \mathrm{U} / \mathrm{L}$ after 25 days of cultivation in a defined medium. Copper (II) ions $(0.4 \mathrm{mM})$, Tween $80(1.0 \mathrm{mM})$ and ascorbic acid $(5.0 \mathrm{mM})$ increased the production of laccase. The optimum temperature for enzyme operation is in the range of $30-40{ }^{\circ} \mathrm{C}$ and retains over $60 \%$ of the maximum activity at $10{ }^{\circ} \mathrm{C}$. New laccase shows high thermolability-half-life at $40^{\circ} \mathrm{C}$ was only $60 \mathrm{~min}$. Enzyme degradation of synthetic dyes was the highest for crystal violet, i.e., $48.6 \%$ after 1-h reaction with ABTS as a mediator. Outcomes of this study present the K. bupleuri laccase as a potential psychrozyme for environmental and industrial applications.
\end{abstract}

Keywords: laccase; psychrophilic; Kabatiella bupleuri; decolorization; synthetic dyes

\section{Introduction}

Laccase is an enzyme belonging to the group of multicopper oxidases and catalyzing the oxidation in which a substrate loses a single electron and is converted to a free radical. The resulting unstable radical may further undergo laccase-catalyzed oxidation or non-enzymatic reactions such as hydration, disproportionation and polymerization. In laccase-catalyzed reactions, diphenols undergo 4-electron oxidation. During this reaction, the $\mathrm{Cu}(\mathrm{II})$ ion is reduced to the $\mathrm{Cu}(\mathrm{I})$ ion. Moreover, $\mathrm{Cu}(\mathrm{I})$ reduces molecular oxygen $\left(\mathrm{O}_{2}\right)$ to produce two water molecules, and is oxidized back to $\mathrm{Cu}$ (II) (Figure 1) [1]. Laccases display a wide substrate specificity, including phenols, phenolic compounds, aminophenols, aromatic amines, lignins and steroid hormones. For this reason, they are used in many different industries, such as paper, petrochemical, food, and textile [2]. The use of laccases adapted to low temperatures is particularly interesting. The textile, paper, printing and tannery industries produce huge amounts of waste containing synthetic dyes toxic to the environment. It is estimated that about $5-10 \%$ of them could remain persistent in wastewater. The use of laccases allows carrying out the processes of their degradation without using chemical and physical methods [3-5]. Laccase can also be used in the processes of detoxification of environments polluted with polycyclic aromatic compounds [6,7]. 


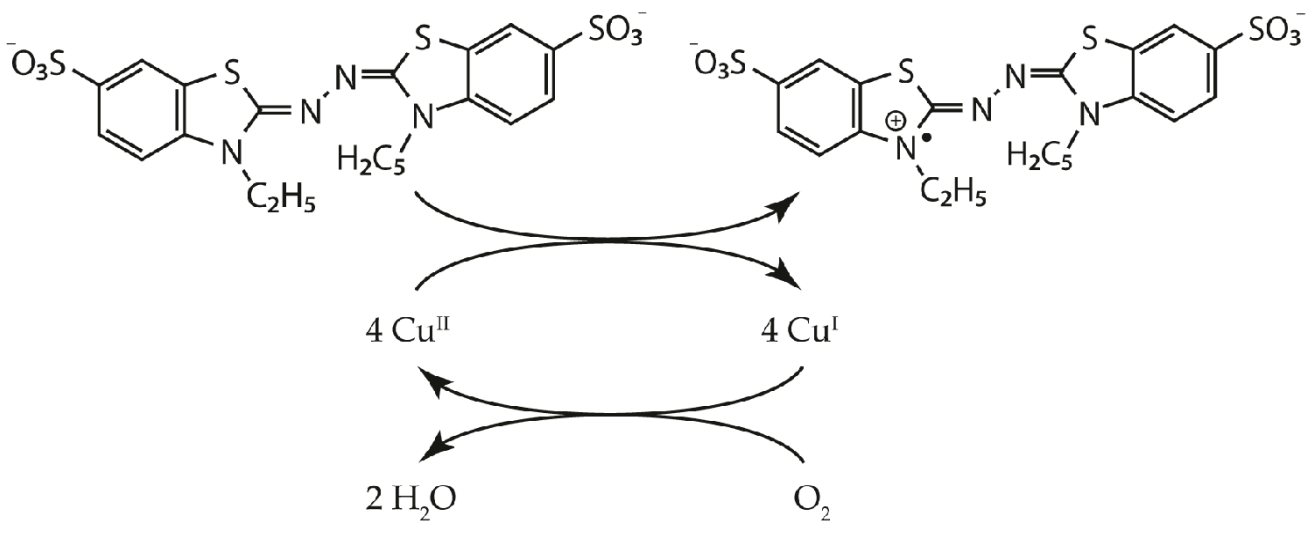

Figure 1. Scheme of a laccase catalytic cycle with 2,2'-azino-bis(3-ethylbenzothiazoline-6-sulfonic acid (ABTS) as a substrate, according to Riva, 2006 [8].

Laccases are products of secondary metabolism and their synthesis is influenced by limiting factors, such as the type of culture, its duration and the composition of the medium, or by the addition of inducers, as the genes encoding laccases contain regulatory sites, e.g., metal responsive elements (MREs) and xenobiotic responsive elements (XREs) [9]. The most common inducers include $\mathrm{Cu}(\mathrm{II})$ ions, aromatic compounds (veratryl alcohol, vanillic acid, 2,5-xylidine, ferulic acid, syringaldazine, guaiacol, p-hydroxybenzoic acid, 3,4-dimethoxycinnamic acid, 4-hydroxybenzaldehyde, vanillin), vitamins and essential amino acids (tryptophan, methionine, glycine, valine, biotin, riboflavin), organic solvents (ethanol), xenobiotics (4-n-nonylophenol, aniline, oxidized derivatives of diquat and $\mathrm{N}, \mathrm{N}^{\prime}$-dimethyl-N-(5-chloro-4-hydroxyphenyl), urea, surfactants (Tween 80 ) and ethidium bromide [10].

Laccases are ubiquitous enzymes in nature. They were isolated from higher plants, insects and bacteria, but their main source is white rot fungi. The first plant laccase was isolated from a Japanese tree, Rhus vernicifera [11]. Fungal laccases were isolated later, in 1896, by Bertrand [12]. Among the fungi producing this enzyme we can distinguish Trametes versicolor, Trametes ochracea, Trametes hirsuta, Cerrena maxima and Coriolopsis polyzona, and among bacteria-Escherichia coli, Bacillus subtilis, Streptomyces antibioticus and Azospirillum lipoferum $[9,13]$.

In this study we conducted a screening of psychrophilic and cold-adapted yeast and yeast-like fungi for the production of laccases working at low temperatures. Decreasing the temperature enables lowering of the costs of energy needed for heating the waste-on the contrary, the process can be conducted at the site of contamination. Despite the undoubted advantages of low-temperature-adapted enzymes, little information is available on psychrophilic laccases. Rovati et al. [14] noted the laccase activity at $15^{\circ} \mathrm{C}$ from 25 yeast strains isolated from soil samples from de Mayo/King George Island. Certain adaptations to low temperatures were also observed for the laccase from Cryptococcus albidus (renamed to Naganishia albida) [15] and from Colletotrichum lagenarium [16].

The characterization of the Kabatiella bupleuri laccase conducted in this study showed that it is an enzyme of interest from a biotechnological point of view and that it can be used in in situ decolorization of synthetic dyes.

\section{Materials and Methods}

\subsection{Organism Selection and Culture Conditions}

To search for producers of cold-adapted laccases, 41 strains of psychrophilic yeast and yeast-like fungi were used. Furthermore, 17 strains were purchased from the Italian collection, Industrial Yeasts Collection DBVPG (Perugia, Italy). The remaining 26 strains were isolated from soil samples located at 10 different sites in the vicinity of the Henryk Arctowski Polish Antarctic Station on King George Island (62 $09^{\prime} 41^{\prime \prime}$ S, $58^{\circ} 28^{\prime} 10^{\prime \prime}$ W) and 
are a part of the collection of Antarctic microorganisms in the Institute of Molecular and Industrial Biotechnology, Lodz University of Technology (Stefanowskiego 2/22, 90-537, Lodz, Poland) [17]. Cultivation included the following stages:

Plate screening on the selection media containing the inducers of laccase production:

(1) LBM medium supplemented with ABTS (2,2'-azino-bis(3-ethylbenzothiazoline-6sulfonic acid)) (in g/L: 4.0 glucose, $4.0 \mathrm{KH}_{2} \mathrm{PO}_{4}, 0.5$ ammonium tartrate, $0.5 \mathrm{MgSO}_{4} \times 7 \mathrm{H}_{2} \mathrm{O}$, $0.01 \mathrm{CaCl}_{2} \times 2 \mathrm{H}_{2} \mathrm{O}, 0.01$ yeast extract, $0.001 \mathrm{CuSO}_{4} \times 5 \mathrm{H}_{2} \mathrm{O}, 0.001 \mathrm{Fe}_{2}\left(\mathrm{SO}_{4}\right)_{3}, 0.001 \mathrm{MnSO}_{4} \times \mathrm{H}_{2} \mathrm{O}$, 1.0 ABTS, 16.0 agar, $\mathrm{pH}$ 5.5-6.0), and (2) medium with guaiacol (in g/L: 10.0 glucose, 3.0 peptone, $0.6 \mathrm{KH}_{2} \mathrm{PO}_{4}, 0.6 \mathrm{~K}_{2} \mathrm{HPO}_{4}, 0.5 \mathrm{MgSO}_{4}, 0.05 \mathrm{MnSO}_{4} \times \mathrm{H}_{2} \mathrm{O}, 0.001 \mathrm{ZnSO}_{4}, 0.0005 \mathrm{FeSO}_{4}$ ， 0.2 guaiacol, 20.0 agar, $\mathrm{pH} 6.0$ ).

Inoculated plates with selective media were incubated at $20{ }^{\circ} \mathrm{C}$ for $20 \mathrm{~d}$. The development of an intense bluish-green and reddish-brown color around the wells on ABTS or guaiacol substrate, respectively, was considered as a positive test for laccase activity.

1. Submerged culture of laccase producers selected during plate screening on the following media: (1) Olga medium [18], (2) modified Kirk medium (LMM) [19], (3) Sivakumar medium [20] and (4) mineral medium in order to select the most optimal medium for laccase production by the cold-adapted fungi. (1) The Olga medium contained (in $\mathrm{g} / \mathrm{L}$ ): 3.0 peptone, 10.0 glucose, $0.6 \mathrm{KH}_{2} \mathrm{PO}_{4}, 0.001 \mathrm{ZnSO}_{4}, 0.4 \mathrm{~K}_{2} \mathrm{HPO}_{4}, 0.0005 \mathrm{FeSO}_{4}$, $0.05 \mathrm{MnSO}_{4}$ and $0.5 \mathrm{MgSO}_{4}$ (pH 6.0); (2) LMM contained (in g/L): 10.0 glucose, 1.0 yeast extract, 2.0 ammonium tartrate, $1.0 \mathrm{KH}_{2} \mathrm{PO}_{4}, 0.5 \mathrm{MgSO}_{4} \times 7 \mathrm{H}_{2} \mathrm{O}, 0.5 \mathrm{KCl}$ and $0.15 \mathrm{mM} \mathrm{CuSO}_{4} \times 5 \mathrm{H}_{2} \mathrm{O}(\mathrm{pH}$ 5.5-6.0); (3) Sivakumar medium contained (in $\mathrm{g} / \mathrm{L}$ ): 20.0 soluble starch, 2.5 yeast extract, $1.0 \mathrm{KH}_{2} \mathrm{PO}_{4}, 0.05 \mathrm{Na}_{2} \mathrm{HPO}_{4}, 0.5 \mathrm{MgSO}_{4}$, $0.01 \mathrm{CaCl}_{2}, 0.01 \mathrm{FeSO}_{4}, 0.001 \mathrm{MnSO}_{4}, 0.001 \mathrm{ZnSO}_{4}$ and $0.002 \mathrm{CuSO}_{4}$ (pH 5.5); and (4) mineral medium contained (in g/L): 2.0 glucose, $1.0\left(\mathrm{NH}_{4}\right)_{2} \mathrm{SO}_{4}, 1.0 \mathrm{~K}_{2} \mathrm{HPO}_{4}$, $0.5 \mathrm{MgSO}_{4} \times 7 \mathrm{H}_{2} \mathrm{O}, 0.5 \mathrm{NaCl}, 0.01 \mathrm{MnSO}_{4}, 0.001 \mathrm{CuSO}_{4} \times 5 \mathrm{H}_{2} \mathrm{O}(\mathrm{pH} 5.5-6.0)$.

2. Submerged culture of Kabatiella bupleuri strain in the Sivakumar medium with the addition of several potential inducers of laccase biosynthesis (concentrations specified in the Results) such as copper (II) ions, Tween 20, Tween 80, ABTS, guaiacol, syringaldazine, ethidium bromide, catechol, 2,5-xylidine, veratryl alcohol, vanillin and ascorbic acid, in order to find the inducer that causes the highest enzyme activity $(\mathrm{U} / \mathrm{L})$.

3. Submerged culture in the modified Sivakumar medium with the selected inducers (copper (II) ions and Tween 80), in which the starch was replaced by waste products in concentrations of 20 and $100 \mathrm{~g} / \mathrm{L}$ from the agri-food and brewing industry and compounds rich in lignocellulose (carrot pomace, apple pomace, potato pulp, spent grain from the brewery, lignin, rye straw, straw briquette).

The strains were pre-cultured in the rich medium containing $5.0 \mathrm{~g} / \mathrm{L}$ yeast extract and $10.0 \mathrm{~g} / \mathrm{L}$ peptone at $20^{\circ} \mathrm{C}$ for 3 days. This pre-culture $(2.6 \mathrm{~mL})$ was used to inoculate $65 \mathrm{~mL}$ of different laccase producing media in a $250 \mathrm{~mL}$ Erlenmeyer flask. Cultures were conducted for $25-30$ days at $20{ }^{\circ} \mathrm{C}$ with shaking $(150 \mathrm{rpm})$. Inducers were added after 3 days of growth.

\subsection{Laccase Extraction from the Biomass}

Fungi biomass harvested after submerged cultures was disrupted by shaking with glass beads. The wet biomass was disintegrated in $20 \mathrm{mM}$ Tris- $\mathrm{HCl}$ buffer $\mathrm{pH}$ 7.4, enriched with $0.1 \%$ Triton-X100, $100 \mathrm{mM} \mathrm{KCl}, 8 \mathrm{mM} \mathrm{MgCl} 2,150 \mathrm{mM} \mathrm{NaCl}$ and $1 \mathrm{mM}$ PMSF. The sample was vortexed for $30 \mathrm{~s}$ and left on ice for $30 \mathrm{~s}$. The procedure was repeated 12 times. The sample was centrifuged at $1500 \times g$ for $5 \mathrm{~min}$ at $10^{\circ} \mathrm{C}$ and the insoluble cell debris was discarded.

\subsection{Genetic Identification of Laccase-Producing Strain}

\subsubsection{DNA Extraction}

Yeast and yeast-like strains were cultivated in the flasks with medium containing $20.0 \mathrm{~g} / \mathrm{L}$ glucose, $10.0 \mathrm{~g} / \mathrm{L}$ yeast extract and $20.0 \mathrm{~g} / \mathrm{L}$ peptone at $20{ }^{\circ} \mathrm{C}$ and $150 \mathrm{rpm}$. 
Biomass was centrifuged $\left(5000 \times \mathrm{g}, 10 \mathrm{~min}, 4{ }^{\circ} \mathrm{C}\right)$ and frozen at $-80^{\circ} \mathrm{C}$. Next, $100 \mathrm{~g}$ of frozen biomass was ground in the mortar with the liquid nitrogen to a uniform powder and transferred to a $15 \mathrm{~mL}$ Falcon tube. One milliliter of the extraction buffer $(200 \mathrm{mM}$ Tris- $\mathrm{HCl}$, pH 7.5; $25 \mathrm{mM}$ EDTA, pH 8.0; 0.5\% SDS; $250 \mathrm{mM} \mathrm{NaCl}$ ) and $2 \mathrm{~mL}$ of the phenol:chloroform:isoamyl alcohol (25:24:1, v:v:v) mixture was added; the tube was gently shaken for $10 \mathrm{~min}$ at the room temperature and centrifuged at $11,000 \mathrm{rpm}$ for $30 \mathrm{~min}$. Water phase was collected, supplemented with $5 \mu \mathrm{L} 10 \mathrm{mg} / \mathrm{mL}$ RNAse (EURx, Gdansk, Poland), incubated for $1 \mathrm{~h}$ at $37^{\circ} \mathrm{C}$, and extracted (equal-volume) with phenol:chloroform:isoamyl alcohol (25:24:1, v:v:v) with vigorous shaking. Water phase was collected after centrifugation $\left(13,000 \mathrm{rpm}, 15 \mathrm{~min}, 4^{\circ} \mathrm{C}\right)$. DNA was precipitated by addition of 0.1 volume of $3 \mathrm{M}$ sodium acetate $\mathrm{pH} 5.2$ and 0.6 volume of ice-cold isopropanol. The sample was incubated over night at $20^{\circ} \mathrm{C}$ and centrifuged $\left(15,000 \mathrm{rpm}, 15 \mathrm{~min}, 4^{\circ} \mathrm{C}\right)$. DNA precipitate was washed twice with $70 \%$ ethanol $(150 \mu \mathrm{L})$, centrifuged and dried for 2-3 min. DNA was dissolved in $60 \mu \mathrm{L}$ of sterile RNAse-free distilled water.

\subsubsection{PCR Amplification of D1/D2 and ITS1-5,8S-ITS2 Regions}

PCR amplification of the D1/D2 regions of 26S rDNA domain and ITS1-5,8S-ITS2 region were performed using primers LR6/ITS5 and RLR3/V9 (Table 1), respectively, with genomic DNA as a template. The reaction condition of PCR was an initial denaturation step at $98^{\circ} \mathrm{C}$ for $3 \mathrm{~min} ; 40$ cycles at $98^{\circ} \mathrm{C}$ for $30 \mathrm{~s}$ denaturing, annealing at $44^{\circ} \mathrm{C}$ for $30 \mathrm{~s}$ and extension at $72{ }^{\circ} \mathrm{C}$ for $48 \mathrm{~s}$; a final extension of $72{ }^{\circ} \mathrm{C}$ for $5 \mathrm{~min}$ followed by maintenance at $4{ }^{\circ} \mathrm{C}$. PCR products were purified using a GeneMatrix Basic DNA Purification Kit (EURx, Gdansk, Poland) and sequenced using starters NL1FWD/NL4REV for region D1/D2 and ITS1/ITS4 for fragment ITS1-ITS2 (Table 1).

Table 1. Sequence of primers used for genetic identification of laccase producing strain.

\begin{tabular}{cc}
\hline Name of Primers & Sequence $\left(\mathbf{5}^{\prime} \rightarrow \mathbf{3}^{\prime}\right)$ \\
\hline & For amplification \\
ITS5 & GGAAGTAAAAGTCGTAACAAGG \\
LR6 & CGCCAGTTCTGCTTACC \\
RLR3 & GGTCCGTGTTTCAAGAC \\
V9 & TGCGTTGATTACGTCCCTGC \\
\hline NL1FWD & For sequencing \\
NL4REV & GCATATCAATAAGCGGAGGAAAAG \\
ITS1 & GGTCCGTGTTTCAAGACGG \\
ITS4 & TCCGTAGGTGAACCTGCGG \\
& TCCTCCGCTTATTGATATGC \\
\hline
\end{tabular}

\subsubsection{Data Analysis}

Sequences of region D1/D2 and fragment ITS1-ITS2 were analyzed in Nucleic Acid Sequence Massager (http:/ /www.cmbn.no/tonjum/seqMassager-saf.htm) (accessed on 1 June 2017) and compared to the sequences in GenBank at NCBI (http:/ / www.ncbi. nlm.nig.gov/) (accessed on 27 April 2021) using the BLASTn algorithm at NCBI. The phylogenetic trees were calculated by the fast minimum evolution method using the results obtained using BLAST pairwise alignments.

\subsection{Raw Materials}

Apple pomace, carrot pomace, potato pulp, rye straw and brewer's spent grain (BSG) (approx. $80 \%$ moisture content) were dried at $60{ }^{\circ} \mathrm{C}$ to $90 \%$ dry matter to be stored safely. Lignin (Matocell, TZMO SA, Torun, Poland) was crushed to an average particle size of about $1 \mathrm{~cm}$. Straw briquette (Eko-Pellets, Nowy Tomysl, Poland) was in the form of light, straw-colored cylindrical particles with diameter about 6-8 $\mathrm{mm}$ and length about 5-50 $\mathrm{mm}$. Materials were sterilized at $121^{\circ} \mathrm{C}$ for $15 \mathrm{~min}$ before being used in culture. 
Chemical characterization of BSG including estimation of cellulose, hemicellulose, lignin, crude protein content and ash content was determined according to Meneses et al. [21].

\subsection{Purification of the Laccase by Ammonium Sulphate Fractioning}

Laccase G3 was extracted by the method of fractional desalting. Post-culture liquid was centrifuged and ammonium sulphate was added in portions until the final concentration of $40 \%$ to the supernatant placed on ice. After 1-h incubation and centrifugation $(8000 \times g, 10 \mathrm{~min})$, another portion was added to the supernatant until final concentration of $60 \%$. The process was repeated twice more to obtain $80 \%$ and $100 \%$ saturation with ammonium sulphate. The pellet containing precipitated laccase was recovered by centrifugation at $8000 \times \mathrm{g}$ for $10 \mathrm{~min}$ at $4{ }^{\circ} \mathrm{C}$ and then dissolved in $10 \mathrm{mM}$ acetate buffer $\mathrm{pH}$ 5.5. The pre-purified laccase extract was dialyzed for $24 \mathrm{~h}$ against water and then analyzed for its activity and protein concentration. Samples were concentrated prior to SDS-PAGE analysis in the Amicon Ultra-15 centrifugal filter units with MWCO of $10 \mathrm{kDa}$ (Merck Millipore, Burlington, MA, USA).

\subsection{SDS-PAGE}

Molecular mass of the laccases was determined by SDS-PAGE [22] in $12 \%$ polyacrylamide gel and $0.1 \mathrm{M}$ Tris-glycine buffer $\mathrm{pH}$ 8.3. Samples were denatured for $10 \mathrm{~min}$ at $96{ }^{\circ} \mathrm{C}$ in a sample buffer with $1 \%$ SDS and $10 \% \beta$-mercaptoethanol. Precision Plus Protein Unstained Standards (Bio-Rad, Hercules, CA, USA) were used as mass standards. Bands were visualized with Bio-Safe Coomassie Stain (BioRad, Hercules, CA, USA). Molecular mass was determined using Quantity One software (BioRad, Hercules, CA, USA) on densitometer BioRad GS-800.

\subsection{Effect of Temperature and $p H$ on Laccase Activity and Stability}

The optimum temperature for laccase activity was determined by incubating the reaction mixture over a temperature range of $0-80{ }^{\circ} \mathrm{C}$ at $\mathrm{pH} 3.5$. To investigate the thermostability of the enzyme, it was incubated in the range of $5-80{ }^{\circ} \mathrm{C}$ for $0-120 \mathrm{~min}$ within a $30 \mathrm{~min}$ interval, followed by measuring the remaining enzyme activity at $\mathrm{pH} 3.5$. The effect of $\mathrm{pH}$ on laccase activity and stability was determined using $10 \mathrm{mM}$ Britton-Robinson buffer for $\mathrm{pH}$ 2.0-10.0, at the optimum temperature. The enzyme was incubated for $24 \mathrm{~h}$ and then the relative activity of laccase was determined. All reactions were performed in triplicates.

\subsection{Substrate Specificity of Laccase}

Substrate specificity of laccase from K. bupleuri was estimated using ABTS and syringaldazine $\left(\varepsilon_{526}=6.5 \times 10^{4} \mathrm{M}^{-1} \mathrm{~cm}^{-1}\right.$; conc. $\left.5.5-40.0 \mu \mathrm{M}\right)$ as a substrate. Firstly, optimum $\mathrm{pH}$ for syringaldazine as obtained in $10 \mathrm{mM}$ Britton-Robinson buffer $\mathrm{pH}$ 2.0-10.0 and with $30 \mu \mathrm{M}$ concentration. Activity determination was carried out at $30^{\circ} \mathrm{C}$. Kinetic parameters, namely, $K_{m}$ and $V_{\max }$, were determined using the Lineweaver-Burk plots.

\subsection{Decolorization of Synthetic Dyes}

Four synthetic dyes: methylene blue $(\lambda=668 \mathrm{~nm})$, basic fuchsine $(\lambda=544 \mathrm{~nm})$, Coomassie Brilliant Blue $(\lambda=555 \mathrm{~nm})$ and crystal violet $(\lambda=590 \mathrm{~nm})$ were decolorized with the purified laccase. Stock solutions of dyes were prepared in sterile distilled water. The total volume of the reaction mixture was $2 \mathrm{~mL}$, which contained acetate buffer $(100 \mathrm{mM}$, $\mathrm{pH} 3.5)$, synthetic dye $(250 \mathrm{mg} / \mathrm{L}), 200 \mu \mathrm{L}$ of purified laccase $(0.1 \mathrm{U})$ and $1.0 \mathrm{mM}$ of ABTS as a redox mediator. The mixture was incubated at $30^{\circ} \mathrm{C}$ for $60 \mathrm{~min}$, and then the absorbance was measured. The percentage was determined spectrophotometrically as the relative decrease in absorbance at each maximal absorbance wavelength of the dyes. The decolorization of dye, expressed as dye decolorization (\%) was calculated by means of Formula (1):

$$
\text { decolorization }(\%)=\left[\left(\mathrm{A}_{\mathrm{i}}-\mathrm{A}_{\mathrm{f}}\right) / \mathrm{A}_{\mathrm{i}}\right] \times 100,
$$


where: $A_{i}$-initial concentration of the dye and $A_{f}-$ final concentration of the dye. All reactions were performed in triplicates.

\subsection{Analytical Methods}

Laccase activity was determined by the oxidation of ABTS method [23]. Biomass was discarded $\left(5000 \times g, 15 \mathrm{~min}, 4^{\circ} \mathrm{C}\right)$ and the laccase activity in the supernatant was determined. The non-phenolic dye ABTS is oxidized by laccase to the more stable and preferred state of the cation radical. Oxidation of ABTS was monitored by determining the increase in $\mathrm{A}_{420}\left(\varepsilon_{420}, 3.6 \times 10^{4} \mathrm{M} / \mathrm{cm}\right)$. The reaction mixture contained $1 \mathrm{mM}$ substrate (ABTS), $150 \mu \mathrm{L}$ of $0.05 \mathrm{M}$ sodium acetate buffer $\mathrm{pH} 3.5$, and $50 \mu \mathrm{L}$ of culture supernatant, and was incubated for $10 \mathrm{~min}$. Absorbance was read at $420 \mathrm{~nm}$ in a spectrophotometer against a suitable blank with water instead of the enzyme. One unit $(U)$ was defined as the amount of the laccase that oxidized $1 \mu \mathrm{mol}$ of ABTS substrate per min.

Lignin peroxidase, manganese-dependent peroxidase and manganese-independent peroxidase activity was determined according to Pointing and coworkers [24].

Protein concentration was determined according to Bradford [25] using BSA as a standard [25].

\subsection{Statistical Analysis}

Calculations were done using Microsoft Excel version 2007. Experimental values were reported as the means \pm s.e. Statistical comparisons were made using a one-way ANOVA (Tukey's test, $p<0.05$ ). All calculations of statistical significance were made using the Graph Pad Prism5 and SPSS ver.11. Graphs were plotted using SigmaPlot version 11 and Graph Pad Prism5.

\section{Results and Discussion}

\subsection{Screening of Yeast and Yeast-Like Fungi for Laccase Activity}

The search for a new psychrophilic laccase began with screening of yeast and yeastlike fungi strains on the selection media containing ABTS or guaiacol as indicators of extracellular activity of the enzyme. The plates were incubated for 20 days at $20^{\circ} \mathrm{C}$. A green ring around the colonies on the ABTS medium or a brown one on the guaiacol medium was observed for four strains, i.e., Cryptococcus gastricus DBVPG, Cryptococcus aerius DBVPG, Leuconeurospora sp. D59 IBMiP and strain G3 IBMiP (Figure 2). These strains were then cultivated in Sivakumar, Olga, Kirk and mineral media for 25 days at $20^{\circ} \mathrm{C}$ with $200 \mathrm{rpm}$ shaking. For the first three of them, both the extracellular and intracellular activity of laccase was very low and did not exceed $1 \mathrm{U} / \mathrm{L}$. Much higher activity $(\sim 35 \mathrm{U} / \mathrm{L})$, was determined for the G3 strain IBMiP (Figure 3).

$\mathrm{H}_{2} \mathrm{O}_{2}$ did not alter the oxidation of ABTS, indicating the lack of peroxidase activity. Lignin peroxidase and manganese peroxidase were not detected either.

The growth dynamics of the G3 strain IBMiP indicated that the extracellular laccase is a secondary metabolite. Its maximum accumulation in the supernatant takes place in the stationary growth phase of the strain and on day 20 it reaches the value of $35.21 \pm 0.64 \mathrm{U} / \mathrm{L}$. Protein concentration in the supernatant increases steadily during the cultivation, regardless of G3 laccase biosynthesis, and on day 20 it is at the level of approx. $46 \mathrm{mg} / \mathrm{L}$ (Figure 3). 


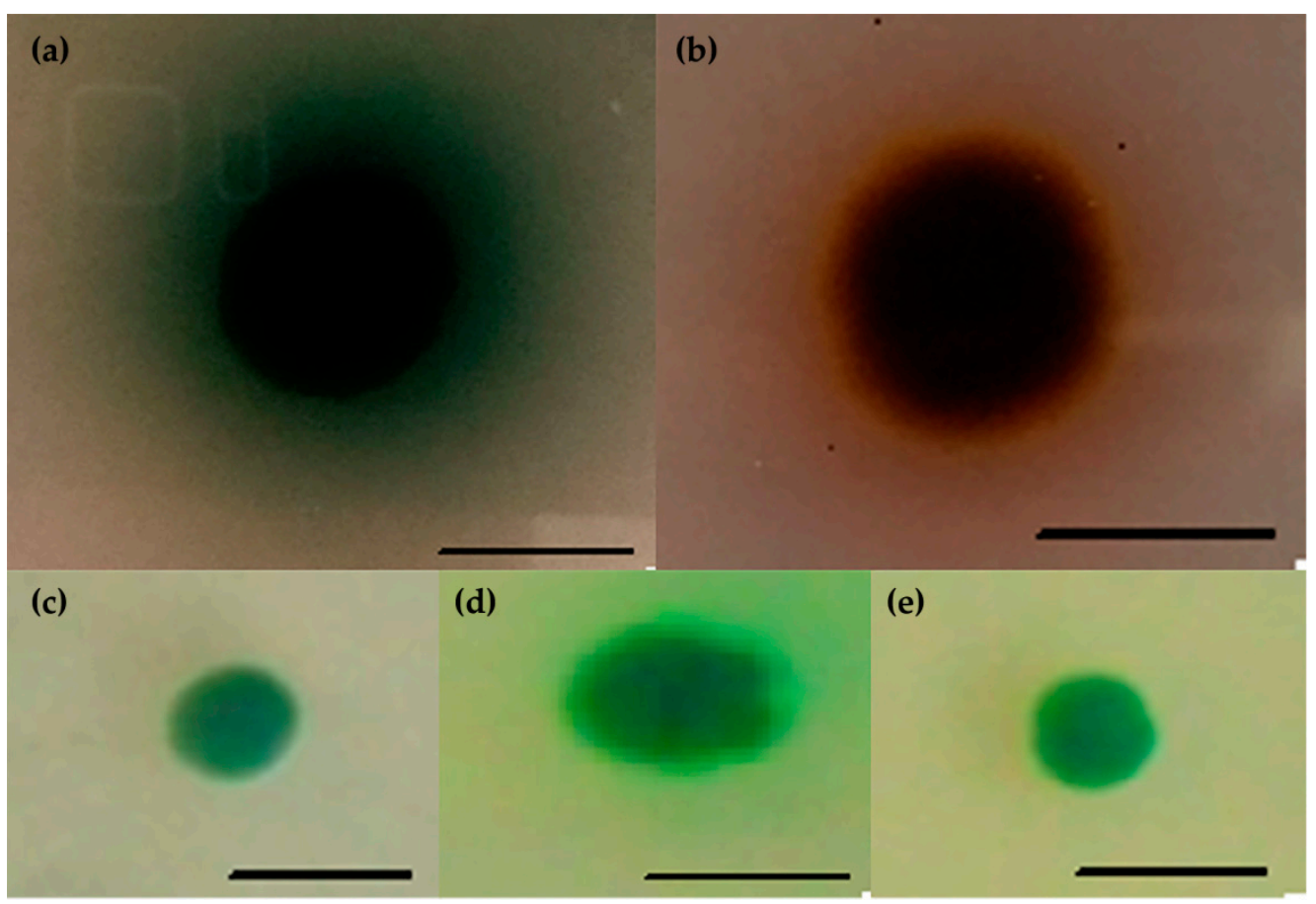

Figure 2. Screening for laccase synthesis. (a) Strain G3 IBMiP on medium with ABTS; (b) strain G3 IBMiP on medium with guaiacol; (c) Leuconeurospora sp. D59 IBMiP on medium with ABTS; (d) Cryptococcus gastricus DBVPG on medium with ABTS; (e) Cryptococcus aerius DBVPG on medium with ABTS. Black bars indicate the length of $10 \mathrm{~mm}$.

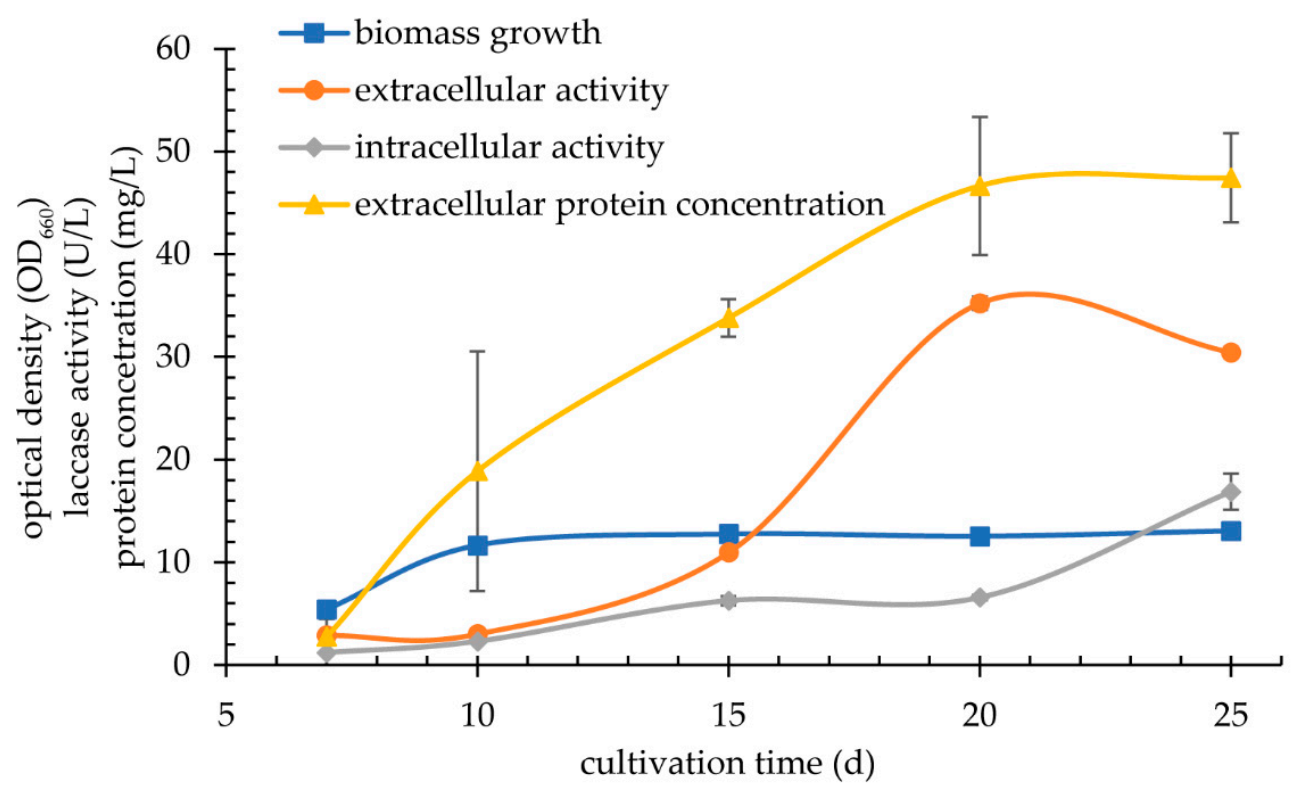

Figure 3. Growth, protein content, extracellular and intracellular laccase activity in the culture of strain G3 IBMiP in the Sivakumar medium.

\subsection{Genetic Identification of Strain G3 IBMiP}

In order to determine the taxonomic identification of the G3 IBMiP strain, genomic DNA was isolated and the fragments encoding the D1/D2 region of the large 26S rDNA subunit and the ITS1-5,8S-ITS2 region between the genes encoding the $18 \mathrm{~S}$ and $26 \mathrm{~S}$ rDNA subunits were amplified. Purified DNA fragments were sequenced and aligned using BLASTn with the homologous sequences deposited in GenBank. The obtained amplicon sequences were deposited into GenBank (accession numbers MW450856.1 and 
MW450864.1). The coding sequence for the D1/D2 region showed more than $99 \%$ similarity to that of the Kabatiella bupleuri strain F278240 (JN886792.1), while for the sequence of the ITS1 and ITS2 region, the greatest similarity was observed for K. bupleuri CBS 131304 (NR_121524.1). The morphological, physiological and biochemical characteristics of the strain confirmed its belonging to the species K. bupleuri (data not shown).

Phylogenetic trees were prepared to investigate the similarity of the strain G3 IBMiP to other yeast (Supplementary Materials Figures S1 and S2). The results revealed a high similarity of K. bupleuri to the genera Aureobasidium or Hormonema, to which they were originally classified. However, molecular analysis of rRNA-encoding genes by Bills et al. [26] allowed for identification of the new species. Further research carried out in the USA and Thailand confirmed the differences between the genera Aureobasidium and Kabatiella in terms of different growth conditions [27].

\subsection{Optimization of Growth Conditions of K. bupleuri to Increase Laccase Biosynthesis Inducers for Laccase Synthesis}

In order to facilitate the extracellular activity of K. bupleuri laccase G3 in the previously selected Sivakumar medium, the concentration of copper (II) ions was increased 40- and 100-fold compared to the starting medium $\left(0.01 \mathrm{mM} \mathrm{Cu}^{2+}\right.$; the values were selected based on the literature data $[28,29])$. Copper (II) ions are considered to be an efficient inducer of laccase biosynthesis as they are part of the active site by being involved in the transfer of electrons. Most monomeric laccases contain four copper atoms at the following sites: the type I copper (T1), type II copper (T2) and two of type III copper (T3). The T2 and T3 copper sites form a trinuclear center that is involved in the catalytic mechanism of the enzyme [1].

The addition of copper (II) ions to the medium significantly increased the laccase activity in the supernatant by approx. 50\% for 20 days (Figure 4 ). The highest activity, about $50 \mathrm{U} / \mathrm{L}$, was recorded after 24 days of cultivation in a medium with $0.4 \mathrm{mM} \mathrm{CuSO}_{4}$. Similar activity values were observed for the higher concentration of copper ions. Therefore, taking into account the economic advantages of the process, a lower concentration was used in further studies for the biosynthesis of laccase. It has been demonstrated that copper (II) ions are an effective inducer of laccase production at concentrations of $0.15-5.0 \mathrm{mM}[7,28-36]$. Chen et al. described a significant role of this enhancer in regulating the expression of genes encoding laccases in Volvariella volvacea V14 [31]. By gradually increasing the concentration of $\mathrm{Cu}^{2+}$ to $0.2 \mathrm{mM}$, an increase in the amount of RNA was observed. At the higher concentration $(0.3 \mathrm{mM})$ the effect was opposite and a $70 \%$ decrease in the amount of transcript was observed. Guo et al. observed $30 \times$ higher activity of an extracellular laccase at $1.0 \mathrm{mM} \mathrm{Cu}^{2+}$ [37]. The production of the enzyme was also facilitated by these ions at concentrations of 1.5-2.0 mM for Trametes pubescens MB89. The authors have also demonstrated the impact of time of the addition of the ions to the medium-addition at day 4 was the most favorable [38]. Both Galhaup and Haltrich [38] and Klonowska et al. [30] observed that the addition of copper (II) ions to the sterile medium partially inhibited the growth of fungal biomass and, consequently, the amount of laccase produced. A similar effect was noted with too-late dosing of these ions to the substrate. This was also confirmed in the present study, where the best effect of induction of G3 laccase production by the K. bupleuri strain was observed when copper (II) ions were added to the medium after 3 days of growth. In the case of laccase produced by Monilinia fructicola, it was the day 2 of culture. In the presence of $1 \mathrm{mM} \mathrm{Cu}^{2+}$ and $\mathrm{Mg}^{2+}$ ions, a 5-fold increase in the activity of this enzyme was observed in the post-culture liquid compared to the culture without inducers [39]. 


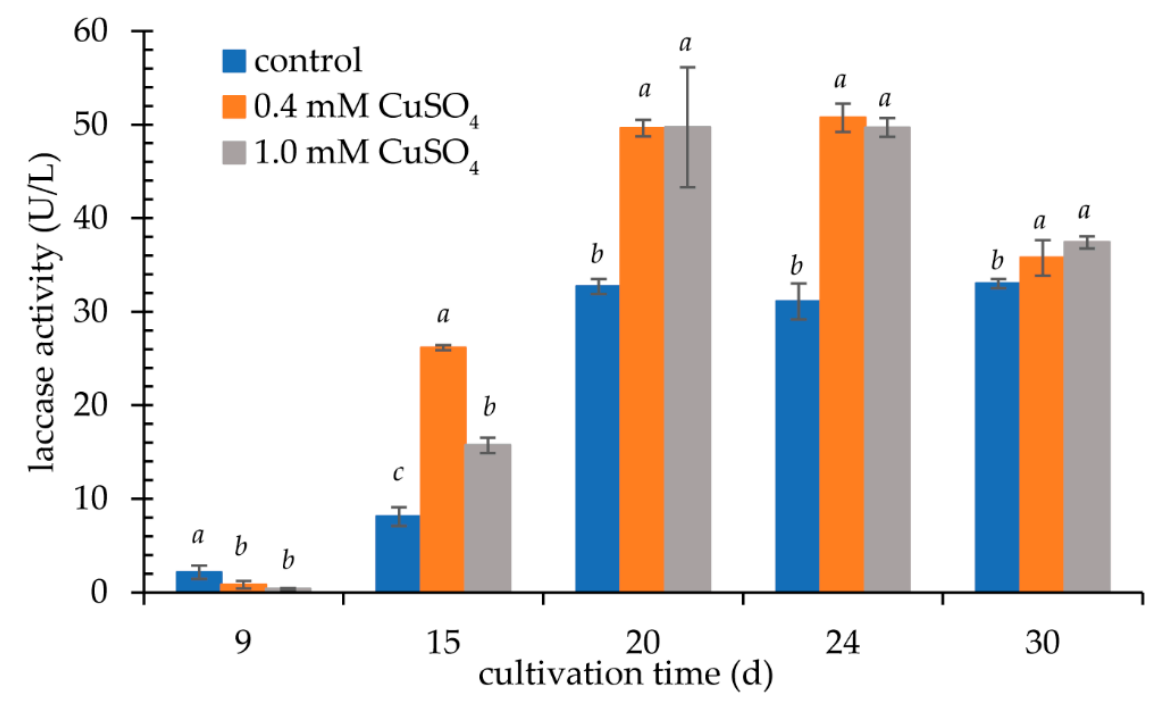

Figure 4. Influence of $\mathrm{Cu}^{2+}$ on laccase activity (cultivation in Sivakumar medium); the data presented as the means \pm SD from at least three independent experiments; the means within single culture day that are marked with different letters $(a-c)$ are significantly different.

The obtained level of K. bupleuri laccase activity after induction with copper (II) ions was still too low to be able to test the potential of the selected oxidoreductase. Therefore, the medium with the addition of the ions was subjected to further modifications and enriched with various groups of compounds for which an activating effect on laccase biosynthesis was shown: (1) surfactants (Tween 20, Tween 80), (2) electron mediators in oxidoreductive reactions (ABTS, guaiacol, syringaldazine), (3) compounds structurally similar to substances that naturally induce the synthesis of ligninolytic enzymes (catechol, 2,5-xylidine, veratryl alcohol, vanillin), and ethidium bromide. Each of these compounds was added to the medium in various concentration ranges (data not shown) and their effect on G3 laccase activity was examined. Figure 5 and Table S1 show the optimal inducer concentrations at which the maximum level of extracellular enzyme activity was reached.

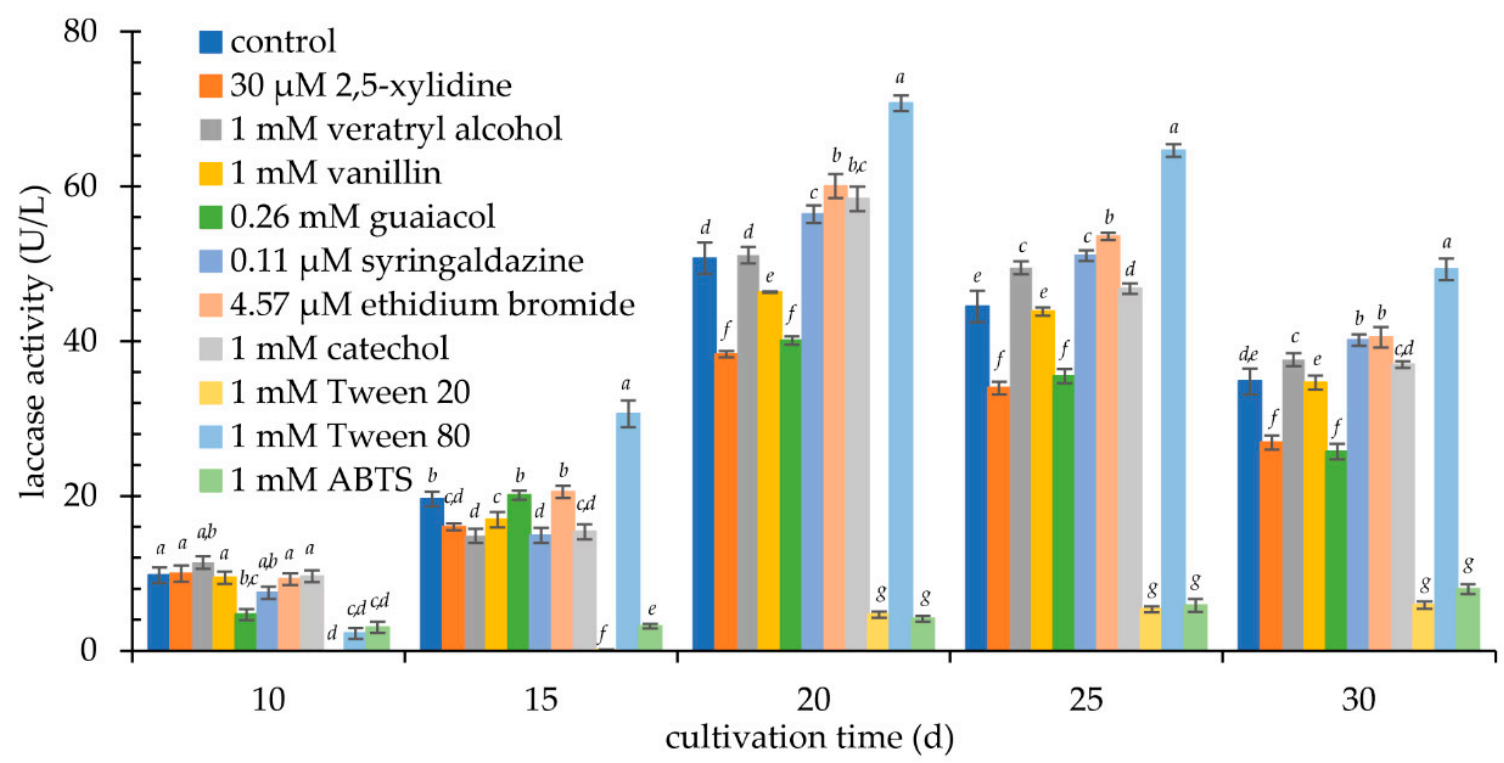

Figure 5. Influence of inducers (at the optimal concentration) on extracellular laccase activity (U/L) during 30-day culture; The data presented as the means \pm SD from at least three independent experiments; the means within single culture day that are marked with different letters $(a-g)$ are significantly different. 
A clear positive effect on the activity of laccase in K. bupleuri culture was found for Tween 80. After 20 days of cultivation in a medium enriched with $0.4 \mathrm{mM} \mathrm{Cu}^{2+}$ and $1 \mathrm{mM}$ Tween 80 , over $50 \%$ increase in activity to the level of about $70 \mathrm{U} / \mathrm{L}$ was observed. This nonionic surfactant is added to the medium, e.g., to increase the secretion of proteins [40,41]. Similar results were obtained for other fungal laccases from Marasmius quercophilus [30], Pholiota sp., Peniphora sp. and Peniophora sp. [42]. The impact of Tween 80 was also investigated by Pointing et al., however, it was less significant than 2,5-xylidine as an inducer for the production of laccase by Pycnoporus sanguineus CY788 [24]. In turn, for the optimal synthesis of laccase by P. sanguineus G05, a medium containing Tween 80 and 2,5-xylidine simultaneously was tested, resulting in an over 6-fold increase in the enzyme activity [43].

A significant positive effect on the activity of $K$. bupleuri laccase was also observed for ethidium bromide, veratryl alcohol, syringaldazine and catechol. These compounds increased their activity by approx. 10-20\% compared to the control sample containing only $0.4 \mathrm{mM} \mathrm{Cu}^{2+}$. Numerous authors have reported an increase in laccase activity as a result of the addition of veratryl alcohol to the culture of Botryosphaeria sp. [44,45], Phlebia brevispora, Phlebia radiata, Daedalea flavida, Polyporus sanguineus [46], T. versicolor [34] and bacterium Chromohalobacter salexigens [47], syringaldazine- to the culture of Coriolus hirsutus [48], ethidium bromide - to the culture of Cyathus bulleri [49], and finally catechol - to the culture of T. versicolor [50]. Catechol was added to the culture at $72 \mathrm{~h}$ of cultivation and after another $24 \mathrm{~h}$, which yielded a 10-fold increase in activity to the level of approx. $1 \mathrm{U} / \mathrm{mL}$. Lower (only 10\% higher laccase activity, than in the control) enhancing ability for catechol was observed by Galhaup and Haltrich [38]. Inducers often reported as effective for laccases, such as 2,5-xylidine [31,38,47,51,52], guaiacol [33,38,46-48], ABTS [34] and vanillin [53] were found ineffective for the G3 laccase and in the research of Guo et al. [37]. Other fungal laccase inducers, however not tested in this study, were reported in the literature: D-phenylalanine [54], phenylhydrazine, 4-methylcatechol [33], organic solvents like ethanol [55-57] or acetone [58], 4-n-nonylphenol [59], actinomycin D [60], ferulic acid [57] and 3,4-dimethoxycinnamic acid [61].

\subsection{Effect of Ascorbic Acid on Laccase Production}

K. bupleuri yeast-like fungi grown in Sivakumar medium produces carotenoid pigments, which causes the biomass to become orange to dark red in color. The production of extracellular K. bupleuri laccase is closely related to the appearance of the amber and, with time, dark brown color of the culture liquid. On completion of the culture, the pigment is observed in the biomass and supernatant. It has been observed that the intensity of its color is correlated with the activity of laccase; the more distinct the color of the post-culture liquid, the higher the activity of the enzyme in the supernatant. This may be due to the fact that laccase-inducing compounds (see Figure 5) increase the biosynthesis level of other oxidoreductases, including, for example, peroxidases, which catalyze the polymerization reactions of carotenoid dye molecules, leading to the formation of aggregates with increased color saturation. Thurston pointed out that in a number of fungi, laccase activity is associated with pigment formation and it is certainly possible that this is its natural role in Aureobasidium pullulans which is closely related to K. bupleuri [62]. The highest activity of laccase was observed for strains producing dark purple or vinaceous pigment. Colorless strains, despite growing on media containing lignin as the only carbon source, showed no laccase activity [52].

The presence of pigment in the supernatant makes further steps of purifying K. bupleuri G3 laccase much more difficult. Therefore, attempts were made to inhibit the dye polymerization process by adding ascorbic acid to the culture medium - an antioxidant compound that increases the stability of carotenoids [63]. As a result of optimization of the concentration of this additive in terms of laccase biosynthesis, it was shown that its supplementation at a concentration of $3.0 \mathrm{mM}$ and $5.0 \mathrm{mM}$ caused a significant increase in the activity of laccase, respectively, by 50 and $100 \%$ after $25 \mathrm{~d}$ compared to the control sample (Figure 6), while reducing the intensity of the color of the supernatant. It is presumed that the reduced 
polymerization of the dye molecules due to the presence of the strong antioxidant made it possible to increase the pool of a free enzyme with the active site readily available for the substrate. Moreover, the addition of ascorbic acid, significantly reducing the color of the supernatant, improved the quality of its filtration and facilitated further stages of enzyme purification.

(a)

\begin{tabular}{cc}
\hline $\begin{array}{c}\text { Ascorbic acid } \\
\text { concentration } \\
(\mathbf{m M})\end{array}$ & $\begin{array}{c}\text { Laccase } \\
\text { activity (U/L) }\end{array}$ \\
\hline control & $62.17 \pm 1.17$ \\
0.1 & $9.23 \pm 0.24$ \\
0.2 & $0.93 \pm 0.03$ \\
0.5 & $8.98 \pm 0.20$ \\
1.0 & $5.53 \pm 0.40$ \\
3.0 & $93.68 \pm 2.55$ \\
$\mathbf{5 . 0}$ & $\mathbf{1 2 6 . 3 6} \pm 3.34$ \\
10.0 & $57.98 \pm 0.08$ \\
\hline
\end{tabular}

(b)

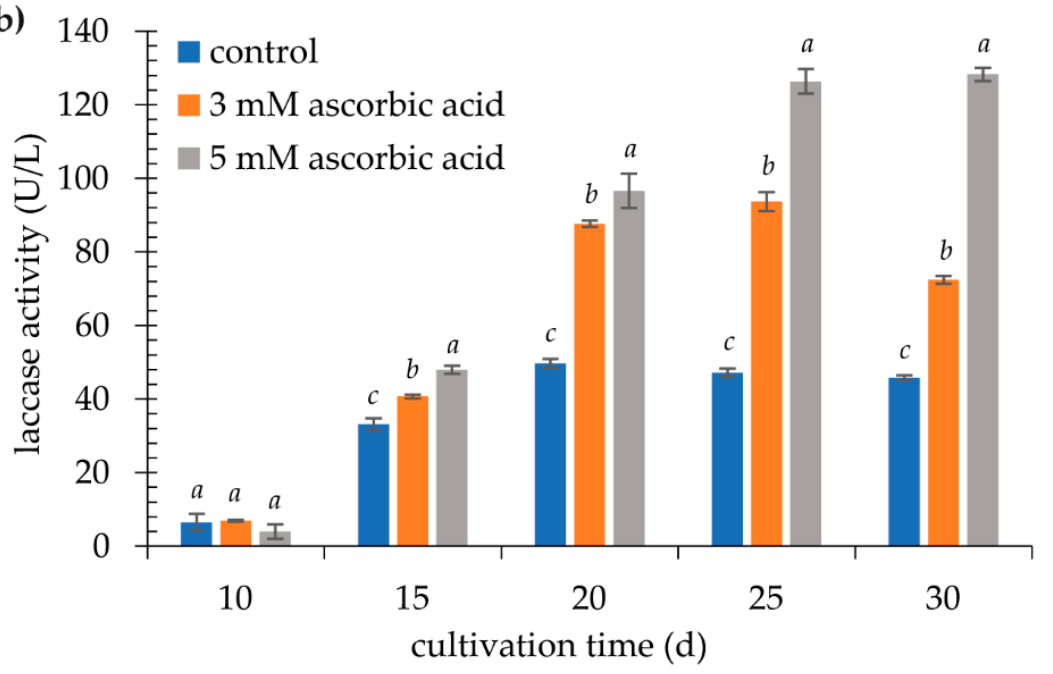

Figure 6. Influence of ascorbic acid on extracellular laccase activity. (a) Laccase activity after 25 days of cultivation with different concentration of ascorbic acid (the maximum activity with $5.0 \mathrm{mM}$ of ascorbic acid is shown in bold); (b) laccase activity during cultivation in medium with $3 \mathrm{mM}$ and $5 \mathrm{mM}$ of ascorbic acid; the data presented as the means \pm SD from at least three independent experiments; the means within single culture day that are marked with different letters $(a-c)$ are significantly different.

\subsection{Waste Materials in Laccase Synthesis}

Taking into account the global pursuit of rational waste management and analyzing the economic considerations of the laccase biosynthesis process, the K. bupleuri G3 strain was cultured in the Sivakumar medium with starch replaced by waste products from the agrifood and brewing industries, such as BSG, carrot pomace, apple pomace, potato pomace, lignins, rye straw and straw briquettes (Figure 7). Their selection was dictated by the high content of lignins, which may be inducers of G3 laccase biosynthesis (Figure 7b). Originally, to select the best waste carbon source, two concentrations were used: 20 and $100 \mathrm{~g} / \mathrm{L}$. The waste material was the only carbon source in the medium. The first concentration, regardless of the type of waste, turned out to be too low for efficient growth of K. bupleuri and extracellular laccase biosynthesis (data not shown). For the latter, the highest enzyme activities were obtained using spent grains from the brewery, BSG (Figure 7a), and the activity levels were similar to those achieved with the starch medium.

An important advantage of laccase biosynthesis using BSG as the only carbon source in the medium was a significant reduction in the cultivation time to reach the maximum enzyme activity ( $130 \mathrm{U} / \mathrm{L})$ - from 20 to 25 , depending on the type of substrate, to 14 days. In the following days, there was a sharp decrease in the activity of laccase in the supernatant, despite the constant increase in the protein concentration (reaching $1.16 \mathrm{~g} / \mathrm{L}$ after 22 days) (Figure 7c). The obtained protein concentrations in the media containing waste products as a carbon source are clearly higher than those determined after culturing in defined media (maximum 30-50 mg/L). This is due to the fact that most of the used plant waste materials are themselves rich in proteins. In further studies, incubation of the uninoculated medium was carried out in parallel to the proper culture to eliminate the protein content from the waste in determination of concentration. 
(a)

\section{Waste material}

Sivakumar medium

with inducers and

ascorbic acid

Apple pomace

Carrot pomace

Lignin

Potato pulp

Spent brewery grain

Straw briquette

Rye straw
$126.36 \pm 3.34$

$16.76 \pm 1.23$

Laccase activity

(U/L)

$0.90 \pm 0.06$

$2.12 \pm 0.15$

$1.68 \pm 0.21$

$130.31 \pm 6.91$

$9.92 \pm 0.50$

$0.11 \pm 0.20$ (b)

\section{Component of BSG g/100 g dry material}

\begin{tabular}{lc} 
Hemicellulose & $20.09 \pm 1.18$ \\
Xylan & $14.56 \pm 0.87$ \\
Arabinian & $5.53 \pm 0.18$ \\
Cellulose & $23.96 \pm 1.74$ \\
Lignin & $19.98 \pm 1.37$ \\
$\quad$ Insoluble in acid & $18.27 \pm 0.34$ \\
$\quad$ Soluble in acid & $1.71 \pm 0.52$ \\
Proteins $(\mathrm{N} \times 6.25)$ & $27.45 \pm 1.97$ \\
Ash & $6.25 \pm 0.61$ \\
\hline
\end{tabular}

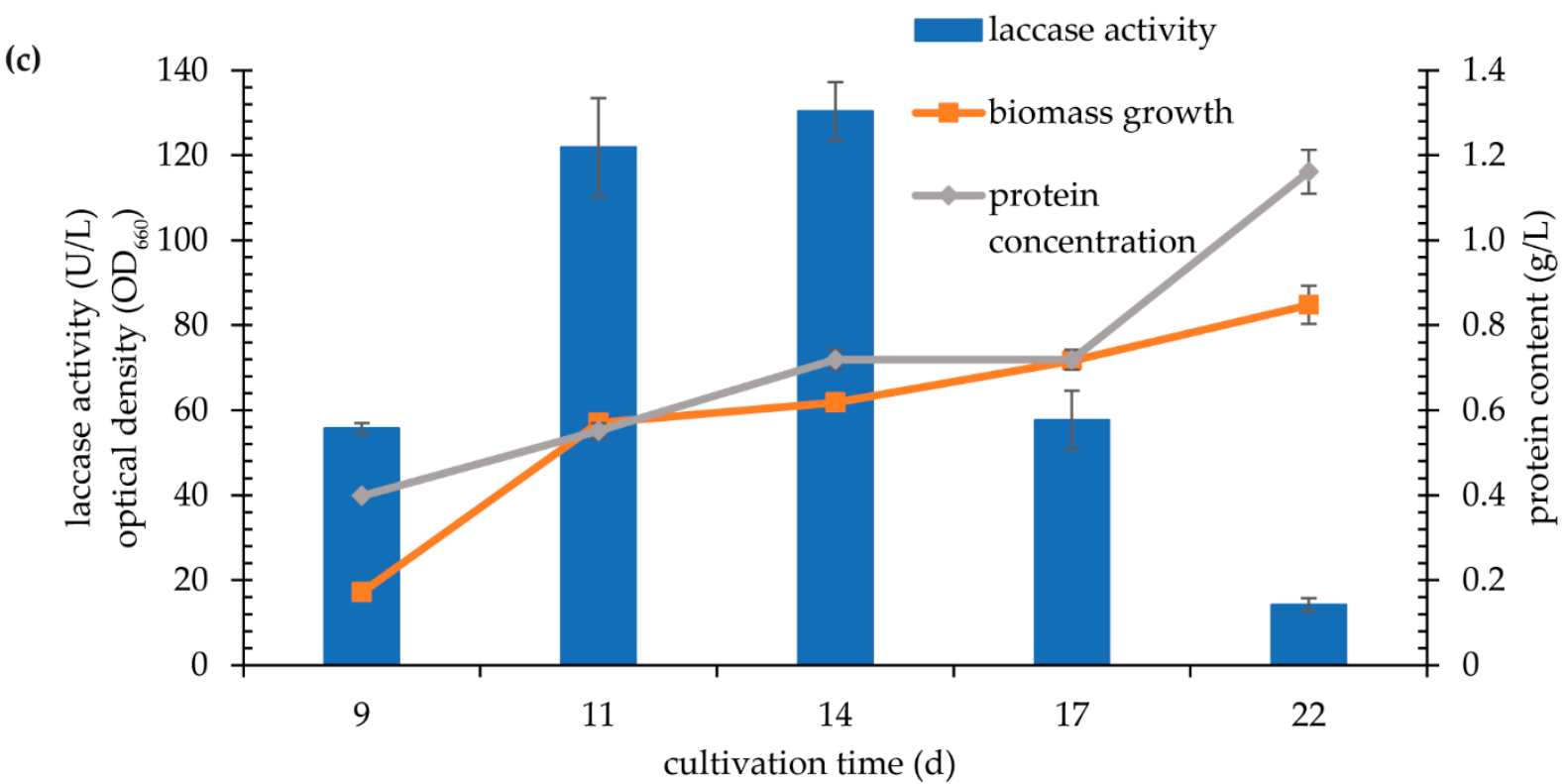

Figure 7. Cultivation of K. bupleuri G3 with waste materials. (a) Laccase activity after cultivation in Sivakumar media (without the presence of additional inducers) enriched with various waste products at a concentration of $100 \mathrm{~g} / \mathrm{L}$ (the maximum activity with brewery spent SG) is shown in bold); (b) chemical composition of; (c) growth, protein content and extracellular laccase activity during cultivation in Sivakumar medium with $100 \mathrm{~g} / \mathrm{L}$ of BSG.

To simplify and minimize substrate costs for efficient $K$. bupleuri laccase biosynthesis, all components of the modified Sivakumar medium (except for spent grains) were replaced with water. This procedure was dictated by the chemical composition of this waste material (Figure $7 \mathrm{~b}$ ). It is rich in hemicellulose, cellulose, lignin and proteins-substances that are a good source of carbon, nitrogen and laccase biosynthesis inducers. The culture was grown in the BSG medium (100 g/L BSG in water with $0.4 \mathrm{mM} \mathrm{Cu}^{2+}$ and $1 \mathrm{mM}$ Tween 80) for 20 days at $20^{\circ} \mathrm{C}$.

The highest activity of extracellular laccase was achieved on the day $15(215.39 \mathrm{U} / \mathrm{L})$. It was about $65 \%$ higher compared to the enzymatic activity obtained for Sivakumar with the addition of inducers and ascorbic acid. Moreover, the activity at the level of approx. $110 \mathrm{U} / \mathrm{L}$ was observed even after 10 days (Figure 8). 


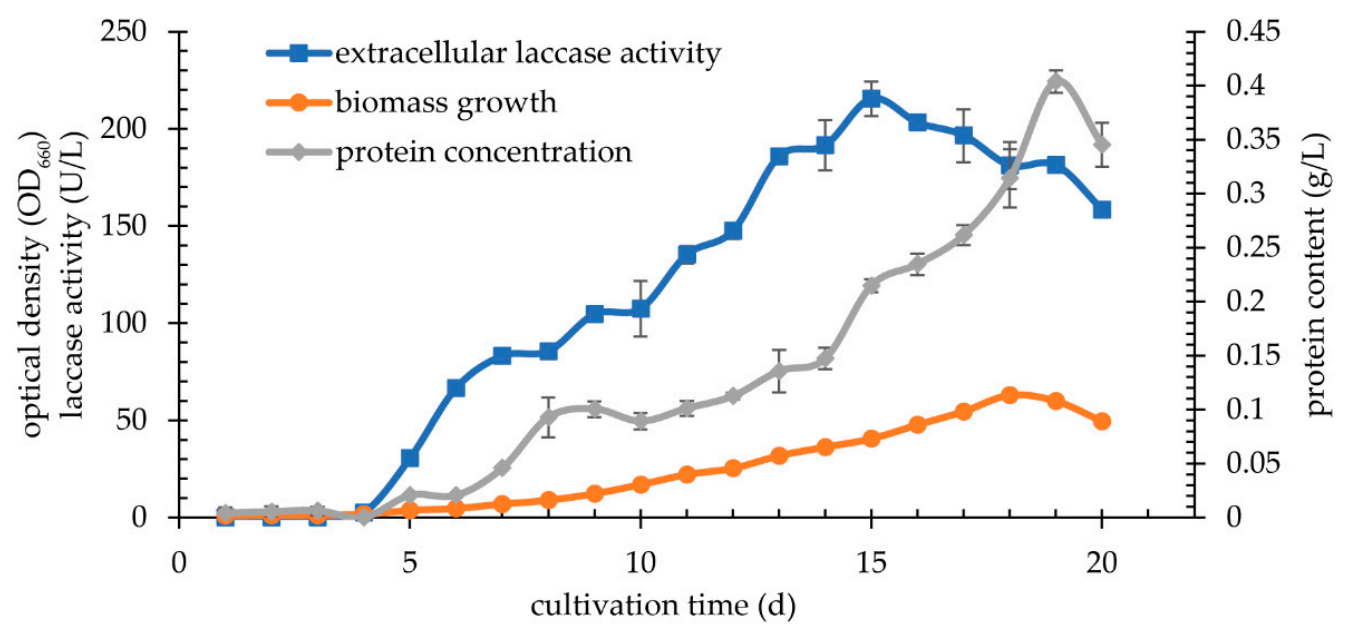

Figure 8. Kinetic of cultivation K. bupleuri G3 in BSG medium.

It can therefore be concluded that the best waste material for the production of laccase by K. bupleuri G3 turned out to be the BSG. This raw material was also used to obtain T. versicolor ATCC 20869 laccase. The solid-state fermentation (SSF) process used BSG with a moisture content of $80-90 \%$ in the amount of $40-500 \mathrm{~g}$. Laccase with an activity of $13,500 \mathrm{U} / \mathrm{g}$ of dry mass was obtained during 12 days of cultivation at $30{ }^{\circ} \mathrm{C}$ [34]. Apple pomace, which turned out to be completely ineffective in the case of K. bupleuri G3 culture, was used to obtain ligninolytic enzyme by Phanerochaete chrysosporium BKMF-1767 [64], and other enzymes including xylanase Aspergillus niger NRRL 567 [65,66], pectinase Bacillus pumilus [67], cellulases A. niger [68] and A. niger NRRL 567 [65], and Macrophomina phaseolina [69]. Among other waste raw materials not tested in this study but used in the production of laccase, tomato pomace was utilized for cultivation of Coriolus versicolor [70].

\subsection{Purification and Characterization of Laccase}

3.6.1. Purification of the Laccase G3 by Ammonium Sulphate Fractionation

To initially purify the laccase from the supernatant, salting out with ammonium sulphate was applied (Table 2).

Table 2. Fractionated salting out of laccase K. bupleuri G3.

\begin{tabular}{cccccc}
\hline Sample & Total Activity & $\begin{array}{c}\text { Total Protein } \\
(\mathbf{m g})\end{array}$ & $\begin{array}{c}\text { Specific Activity } \\
\text { (U/mg) }\end{array}$ & $\begin{array}{c}\text { Yield } \\
(\mathbf{\%})\end{array}$ & $\begin{array}{c}\text { Purification } \\
\text { (fold) }\end{array}$ \\
\hline Crude post-culture supernatant & 4.430 & 14.53 & 0.305 & $100 \%$ & - \\
\hline $40 \%$ saturation of ammonium sulphate & 0.316 & 3.05 & 0.104 & $7 \%$ & 0.34 \\
\hline $60 \%$ saturation of ammonium sulphate & 2.556 & 5.01 & 0.510 & $58 \%$ & 1.67 \\
\hline $80 \%$ saturation of ammonium sulphate & 0.518 & 4.46 & 0.116 & $12 \%$ & 0.38 \\
\hline Supernatant after salting out with 80\% saturation & 0.189 & 1.03 & 0.184 & $4 \%$ & 0.60 \\
\hline
\end{tabular}

Salting out with ammonium sulphate at $40 \%$ saturation of the supernatant allowed for the precipitation of about $21 \%$ of proteins with a total activity of $0.32 \mathrm{U}$. The proteins remaining in the supernatant were further precipitated with ammonium sulphate, reaching $60 \%$ saturation of the solution. This fraction showed the highest specific activity of laccase $(0.5 \mathrm{U} / \mathrm{mg})$, the highest degree of purification (1.67) and the highest process efficiency $(58 \%)$. In the remaining fractions, the specific activity of the target enzyme was much lower (Table 2). 


\subsubsection{SDS-PAGE}

SDS-PAGE was performed for all concentrated protein fractions after salting out. The electropherogram (Figure 9) shows the protein band present in the post-culture supernatant and in one of the fractions for which the highest level of activity was achieved $(60 \%$ saturation, lane 3 at Figure 9; the band is indicated by the red box). Such preliminary purification of the preparation allowed determining of the molecular weight of the tested protein. The laccase produced by K. bupleuri may have a mass of about $70-75 \mathrm{kDa}$ (lane 3, Figure 9). For the remaining fractions, the potential laccase band of the desired molecular weight is very poorly visible, which results from a much smaller overall pool of proteins. Moreover, during the selection of the best waste material for laccase production, the analysis of SDS-PAGE electropherograms showed that the activity of laccase correlates with the presence of the protein band of about 70-75 kDa. In the supernatants where no laccase activity was observed, the band of this size was not identified (results not shown). The size of the G3 laccase is typical for fungal laccase. For example, A. pullulans NRRL 50381 produces a laccase of $60-70 \mathrm{kDa}$, while the enzyme from A. pullulans NRRL Y-2568 has a mass greater than $100 \mathrm{kDa}$ [52]. Laccases produced by fungi from the genus Trametes also have a mass of 60-70 kDa; enzymes from Populus euramericana and Myceliophthora thermophila are slightly heavier-90 and $80 \mathrm{kDa}$, respectively [1].

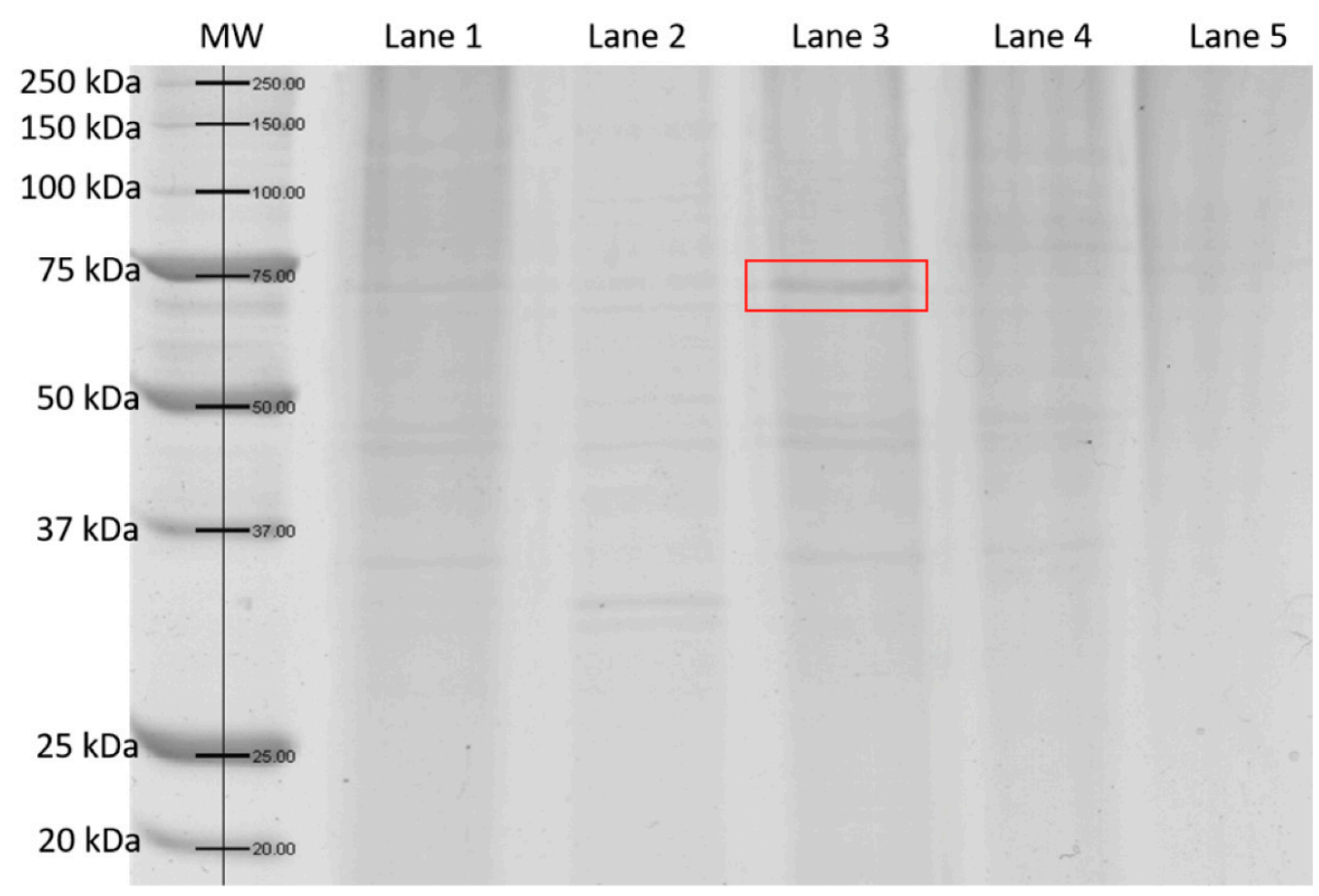

Figure 9. SDS-PAGE after salting out of laccase K. bupleuri; MW: molecular weight marker; Lane 1: crude post-culture supernatant; Lane 2: 40\% saturation; Lane 3: 60\% saturation; Lane 4: 80\% saturation; Lane 5: supernatant after salting out with $80 \%$ saturation of ammonium sulphate. The laccase produced by K. bupleuri may have a mass of about 70-75 kDa (band at the lane 3 indicated using a red box) - the appearance of this band correlated with the highest specific activity of G3 laccase.

\subsubsection{Properties of the Preliminary Purified K. bupleuri Laccase G3}

The optimal conditions for the operation of the pre-purified extracellular laccase produced by the yeast $K$. bupleuri G3 were determined. Maximum activity in the $10 \mathrm{~min}$ reaction with ABTS was observed at temperatures in the range of $30-40{ }^{\circ} \mathrm{C}$. It was noted that $\mathrm{T}_{\mathrm{opt}}$ is not an absolute value as it decreases with increasing reaction time (Figure 10). A temperature of $30^{\circ} \mathrm{C}$ was assumed to be the optimal temperature of action of G3 laccase. The study of the thermostability of this enzyme was carried out in the temperature range $4-80{ }^{\circ} \mathrm{C}$ during $30-, 60$ - and 120 -min incubation. The temperature of $25^{\circ} \mathrm{C}$ did not change 
the enzyme activity after $120 \mathrm{~min}$. For a shorter time, i.e., 30 and $60 \mathrm{~min}$, laccase remains stable at temperatures up to $35^{\circ} \mathrm{C}$, but above this value a very marked decrease in activity has already been observed. It was found that $30 \mathrm{~min}$ incubation of the enzyme at $40{ }^{\circ} \mathrm{C}$ causes a loss of $37 \%$ of the activity, while after 120 min only approx. $20 \%$ of the maximum activity remains. Moreover, the temperature of $50{ }^{\circ} \mathrm{C}$ causes a complete laccase inactivation during 30-min incubation.
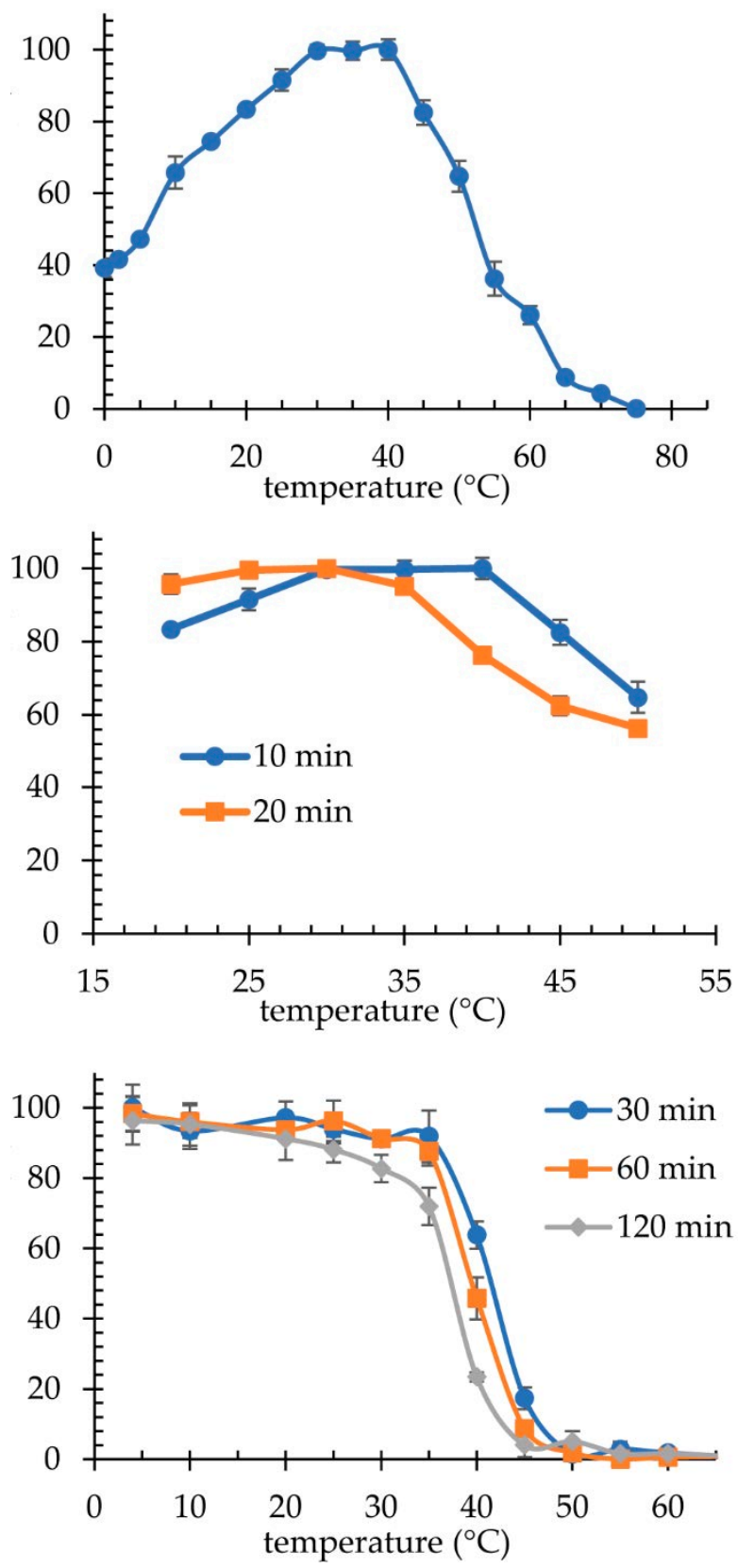

Figure 10. Properties of laccase K. bupleuri: optimal temperature (upper panel) and its variation for different reaction times (middle panel); thermostability during 30-, 60- and 120-min incubation (lower panel).

The high thermolability of G3 laccase, its low optimum temperature $\left(30^{\circ} \mathrm{C}\right)$ and the fact that this enzyme retains over $60 \%$ of its maximum activity at $10{ }^{\circ} \mathrm{C}$ and approx. $40 \%$ at $0{ }^{\circ} \mathrm{C}$, allow classifying of this biocatalyst to the group of enzymes adapted to the action at low temperatures, namely, psychrophilic enzymes. This is extremely important because only a few cold-adapted laccases have been described so far. Moreover, G3 laccase is the 
first enzyme of its kind for which activity was also observed at 0 and $4{ }^{\circ} \mathrm{C}$. Most of the known multicopper oxidases are thermophilic enzymes characterized by high optimal operating temperatures, and the fungal laccases from the literature usually have $\mathrm{T}_{\text {opt }}$ of 50-60 ${ }^{\circ} \mathrm{C}[29,35,45,71-74]$. Homologues with lower $\mathrm{T}_{\text {opt }}$ were also described, e.g., laccases from A. pullulans [51,52], Monilinia fructicola [39], Aureobasidium melanogenum [75], V. volvacea V14 [31] and Cerrena sp. HYB07 [72] operate at high activity at 30-45 ${ }^{\circ} \mathrm{C}$, similarly to the K. bupleuri laccase reported in this study. Lower optimal temperature was reported for Ganoderma lucidum laccases $\left(20-25^{\circ} \mathrm{C}\right.$ ) [76], which additionally retains $65 \%$ of maximum activity in the reaction conducted at $10{ }^{\circ} \mathrm{C}$. At the same time, however, it is characterized by greater thermostability than G3 laccase, maintaining approx. 90\% activity after 4-h incubation at $40^{\circ} \mathrm{C}$. An interesting example of a laccase with a wide range of operating temperatures is the enzyme produced by Pycnoporus sp. SYBC-L1. It shows the highest activity at $70{ }^{\circ} \mathrm{C}$, while at the same time during the reaction carried out at $0{ }^{\circ} \mathrm{C}$ and $10{ }^{\circ} \mathrm{C}$ it retains approx. $30 \%$ and $40 \%$ of the maximum activity, respectively. Interestingly, it also catalyzes the ABTS oxidation reaction at $100{ }^{\circ} \mathrm{C}$, maintaining about $40 \%$ of the maximum activity [32]. Another example of a laccase with a low optimum temperature of action is the enzyme from Cryptococcus albidus (now Naganishia albida) described by Singhal et al. [15]. It is the most active at $\mathrm{pH} 2.5$ and $20-30{ }^{\circ} \mathrm{C}$. It has a relatively low thermal stability, with a half-life of $81 \mathrm{~min}$ at $25^{\circ} \mathrm{C}, 77 \mathrm{~min}$ at $35^{\circ} \mathrm{C}$ and $64 \mathrm{~min}$ at $45^{\circ} \mathrm{C}$ [15]. Another extremely thermolabile enzyme is the laccase from $C$. lagenarium. Its optimal reaction temperature with ABTS is $40^{\circ} \mathrm{C}$, but after $1 \mathrm{~h}$ at $30^{\circ} \mathrm{C}$ it loses $28 \%$ of its activity, and temperatures of 50-60 ${ }^{\circ} \mathrm{C}$ completely inactivate it within $10 \mathrm{~min}$ [16]. Finally, a homologous fungal enzyme, produced by Trichoderma atroviride, retains $100 \%$ and $80 \%$ of the maximum activity after 24-h incubation at $4{ }^{\circ} \mathrm{C}$ and $30^{\circ} \mathrm{C}$, respectively. Only above $50{ }^{\circ} \mathrm{C}$, does 2 -h incubation lead to a clear inactivation of the enzyme, which then retains approx. $20 \%$ of the maximum activity [28]. However, most of the reported laccases remain stable for at least $1 \mathrm{~h}$ at $50{ }^{\circ} \mathrm{C}[52,71,73,74,77,78]$.

The influence of $\mathrm{pH}$ on the activity of G3 laccase produced by K. bupleuri was determined. Maximum activity was observed at $\mathrm{pH} 3.5$ for ABTS and at $\mathrm{pH} 7.0$ for syringaldazine at $30{ }^{\circ} \mathrm{C}$ (Figure 11). This enzyme has a relatively high stability over a wide $\mathrm{pH}$ range. During 24-h incubation of the enzyme in solutions in the range of $\mathrm{pH} 3.5-8.5$, it retains over $80 \%$ of its maximum activity, and in the narrower range of $\mathrm{pH} 4.5-6.0$ as much as $95 \%$ of activity. In an environment with a $\mathrm{pH}$ below $\mathrm{pH} 3.5$ and above $\mathrm{pH} 8.5$, a sharp decrease in activity and inactivation of the enzyme was observed.

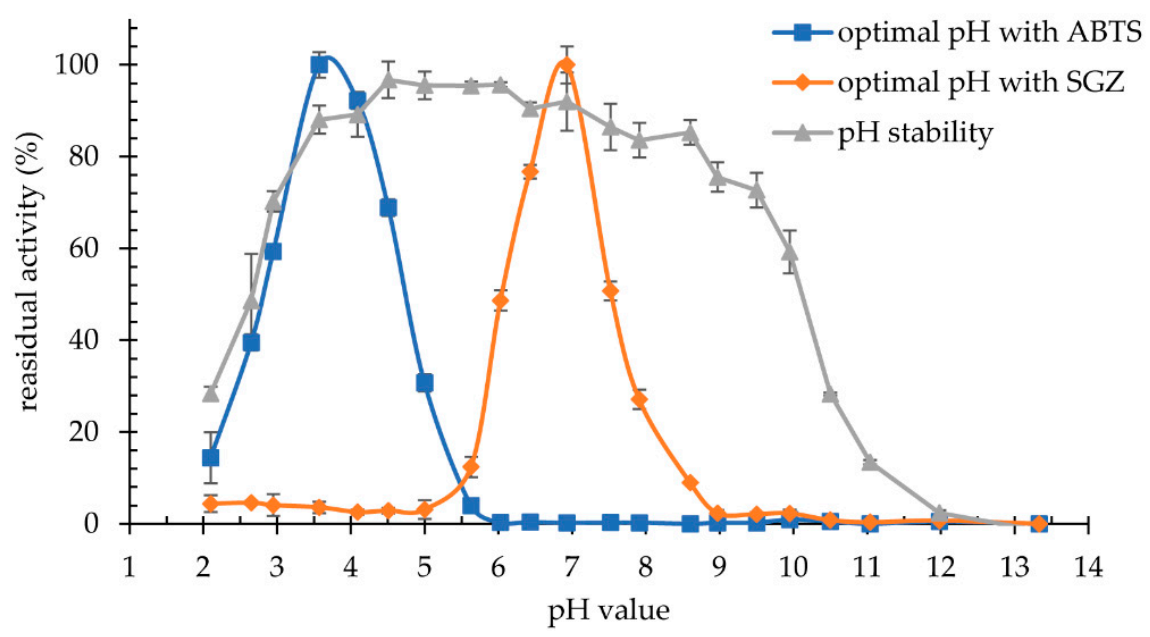

Figure 11. Optimal pH of reaction laccase K. bupleuri G3 with 2,2'-azino-bis(3-ethylbenzothiazoline6-sulfonic acid) (ABTS) and syringaldazine (SGZ) and its $\mathrm{pH}$-stability after 24 -h incubation at $4{ }^{\circ} \mathrm{C}$.

The optimum $\mathrm{pH}$ in reaction with ABTS observed for fungal laccases is most often in the range of 3.0-4.0 [16,28,31,35,45,72,75]. A slightly higher value, pH 5.0, was noted 
for A. pullulans laccases [51] and for Thielavia sp. [74]; and pH 4.5-5.0 for the laccases from $M$. fructicola [39]. A much more acidic operating environment is preferred by laccase produced by Coprinopsis cinerea Okayama 7, with its highest activity towards ABTS is recorded at $\mathrm{pH} 2.5$ [71]. Values of optimal $\mathrm{pH}$ for syringaldazine oxidation are usually higher than observed for ABTS and are in the range of 5.5-7.0 [31,71,77,78]. The $\mathrm{pH}-$ stability of laccases also varies and depends on the manufacturer. Thus, laccases from M. fructicola [39], C. lagenarium [16], T. hirsuta [29] and Thielavia sp. [74] are stable in an acidic $\mathrm{pH}$ range of 3.0-5.0, whereas the laccase from Trametes sp. operates at alkaline $\mathrm{pH} 7.0-9.0$ [35]. Broad $\mathrm{pH}$-stability range was observed for several homologous laccases from Chaetomium sp. (pH 4.0-9.0) [73], Elaeocarpus sylvestris ( $\mathrm{pH} 4.0-10.0)$ [32] and Shiraia sp. SUPER-H168 (pH 4.0-9.0) [78].

The apparent $\mathrm{K}_{\mathrm{m}}$ and $\mathrm{V}_{\max }$ values for ABTS were $0.584 \mathrm{mM}$ and $1.14 \mathrm{U} / \mathrm{mg}$ at $\mathrm{pH} 3.5$, respectively. Moreover, the enzyme from $\mathrm{K}$. bupleuri G3 demonstrated a strong affinity to syringaldazine $\left(\mathrm{K}_{\mathrm{m}}=0.028 \mathrm{mM}, \mathrm{V}_{\max }=0.597 \mathrm{U} / \mathrm{mg}\right)$, which confirmed that the new enzyme is a laccase. Obtained $\mathrm{K}_{\mathrm{m}}$ value for ABTS was lower than for the psychrophilic laccase from C. albidus $\left(\mathrm{K}_{\mathrm{m}}=0.8158 \mathrm{mM}\right)$ [15] and higher than for C. lagenarium laccase $\left(K_{\mathrm{m}}=0.34 \mathrm{mM}\right)$ [16]. However, $\mathrm{K}_{\mathrm{m}}$ value for syringaldazine was similar to values obtained for the laccase from $V$. volvacea $\mathrm{V} 14\left(\mathrm{~K}_{\mathrm{m}}=0.01 \mathrm{mM}, \mathrm{V}_{\max }=4.9 \mathrm{U} / \mathrm{mg}\right)$ [31] and the laccase from C. cinerea $\left(\mathrm{K}_{\mathrm{m}}=0.0226 \mathrm{mM}\right)[71]$.

\subsection{Application of Laccase in Synthetic Dye Decolorization Process}

Laccase produced by K. bupleuri was used in the decolorization of methylene blue, alkaline fuchsin, crystal violet and Coomassie Brilliant Blue R-250 (Table 3).

Table 3. Decolorization of the synthetic dyes using laccase G3.

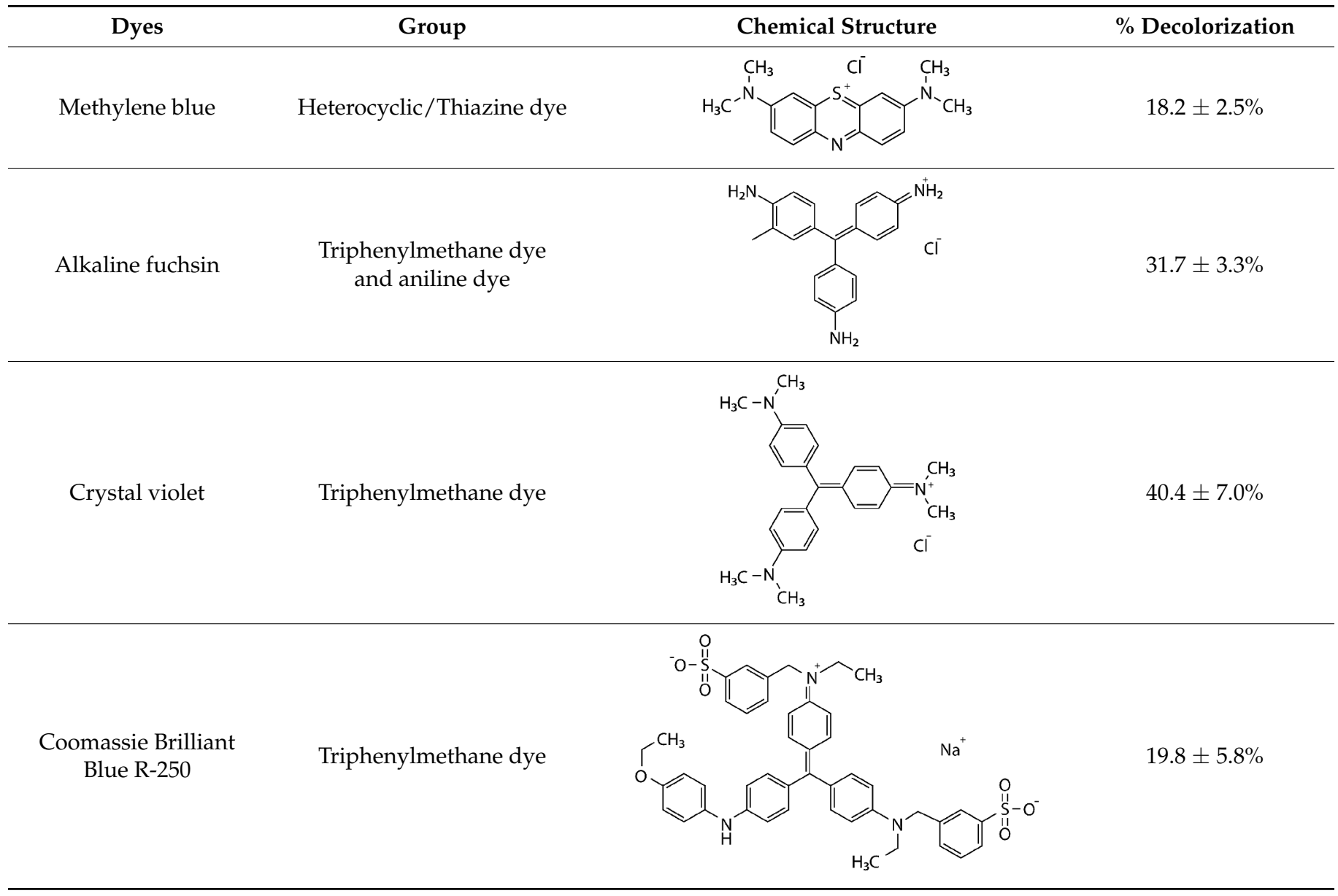


The most popular synthetic dyes in the industry can be divided into azo, heterocyclic/polymeric or triphenylmethanes due to their chemical structure. K. bupleuri laccase can be successfully used in the process of removing dyes such as alkaline fuchsin and crystal violet. Both dyes are used in microbiology in many methods of staining prokaryotic and eukaryotic cells. In addition, alkaline fuchsin is used in molecular biology to stain glycoproteins and nucleic acids, e.g., with Schiff's reagent. Crystal violet is used to dye fabrics. After $1 \mathrm{~h}$ of incubation of $\mathrm{K}$. bupleuri laccase with the tested dyes at $30{ }^{\circ} \mathrm{C}$, decolorization of approx. 32\% and approx. $40 \%$ was observed for fuchsin and crystal violet, respectively. Crystal violet, also known as hexamethyl pararosaniline chloride, is a triphenylmethane dye, while alkaline fuchsin is not a specific dye but a mixture of triarylmethane dyes such as pararosaniline, rosaniline and new fuchsin. The differences in the degree of decolorization of these dyes prove that $K$. bupleuri laccase efficiently oxidizes only selected components of alkaline fuchsin with the structure of pararosaniline derivatives in the presence of a mediator. Moturi and Singara Charya studied the process of crystal violet decolorization by whole fungal cells of Mucor mucedo, Polyporus elegans, T. versicolor and Lenzites betulina [79]. The decolorization process observed during fungal growth ranged from 63 to $78 \%$ after 5 and 15 days of cultivation, respectively. The authors showed that several extracellular enzymes are responsible for this process, including laccases, manganese-dependent peroxidases and lignin peroxidases. Other studies indicated the possibility of using a purified laccase to effectively decolorize crystal violet. The laccase from Pandoraea sp. ISTKB had the ability to remove this dye in $82 \%$ during 1 - $h$ reaction with ABTS as a mediator, but using twice the concentration of the enzyme and a higher temperature than in the present study [80]. On the other hand, Tplac laccase from T. pubescens catalyzes the degradation of dyes without the addition of a mediator. The degree of decolorization of methylene blue was $25 \%$ and $17 \%$ by immobilized and free laccase, respectively, while for crystal violet it was $21 \%$ and $14 \%$, respectively. The process was carried out at $\mathrm{pH} 5.0$ at $50{ }^{\circ} \mathrm{C}$ with the use of an enzyme with an activity of $1 \mathrm{U} / \mathrm{mL}$ [81]. Bacterial laccase derived from the strain Kurthia huakuii LAM0618 also has the ability to degrade the dyes described in this study. In the reaction carried out at $60^{\circ} \mathrm{C}$ for $1 \mathrm{~h}$ in the presence of $0.1 \mathrm{mM}$ ABTS, approx. $35 \%$ degradation of alkaline fuchsin and approx. $60 \%$ degradation of crystal violet were observed. Without the addition of a mediator, the degree of discoloration was lower and amounted to approx. $25 \%$ and approx. $15 \%$, respectively. The process of decolorization of methylene blue in the presence of ABTS was about $80 \%$ effective, and without the mediator, the dye remained intact [82].

Coomassie Brilliant Blue also belongs to the group of triphenylmethane dyes and is used in molecular biology to stain proteins. Forootanfar et al. investigated the effectiveness of three laccases from Aspergillus oryzae, T. versicolor and Paraconiothyrium variabile to decolorize this dye in a shaken culture at $35^{\circ} \mathrm{C}$ [83]. Laccases with an activity of approx. $8 \mathrm{U} / \mathrm{mL}$ and hydroxybenzotriazole (HBT) as a mediator were used. The highest degree of decolorization was observed for $P$. variabile laccase; after 1 -h reaction it was about $55 \%$, and after $3 \mathrm{~h}$ as much as 90\%. The A. oryzae and T. versicolor laccases showed lower efficacy, approx. $5 \%$ and $25 \%$, respectively, after $1 \mathrm{~h}$, and $13 \%$ and $30 \%$ after $3 \mathrm{~h}$ of incubation. In this study, laccase from K. bupleuri only achieved about $20 \%$ of the decolorization degree of Coomassie Brilliant Blue after $1 \mathrm{~h}$ of reaction, which corresponds to the commercial activity of $T$. versicolor laccase.

The last dye tested was methylene blue belonging to the group of heterocyclic dyes. It is a thiazine derivative used in medicine, chemistry and microbiology. The efficiency of decolorization of this dye by K. bupleuri laccase was similar to that of Coomassie Brilliant Blue and amounted to approx. $18 \%$. Similar values were found for P. variabile laccase and it was about $15 \%$ discolored after $1 \mathrm{~h}$ of the reaction and $21 \%$ after $3 \mathrm{~h}$. Commercial laccases from $A$. oryzae and T. versicolor show a much greater activity towards the removal of methylene blue, approximately $90 \%$ and $50 \%$ decolorization, respectively [83]. The degree of dye decolorization, similar to the studied $K$. bupleuri laccase, amounting to approx. $12 \%$, was also found for laccase from Pandoraea sp. ISTKB, but the enzyme's 
concentration was twice as high and the reaction was conducted at a higher temperature of $37^{\circ} \mathrm{C}$ [80]. Lac2 laccase from Cerrena sp. HYB07 in the presence of acetosyringone (ACE) as a mediator showed a high decolorization efficiency of alkaline fuchsin, crystal violet and Coomassie Brilliant Blue, $81 \%, 87 \%$ and $100 \%$, respectively, but using a 20 -fold higher enzyme concentration. The degree of decolorization of methylene blue was clearly lower than that observed for the K. bupleuri laccase, only about 6\% [72]. Similar results were obtained by Ademakinwa and Agboola [84] for A. pullulans laccases- $4.5 \%$ decolorization of the dye in a 3-h reaction, whereas the laccase from Shiraia sp. SUPER-H168 described by Yang et al. [78] did not display any activity towards decolorization of methylene blue.

\section{Conclusions}

The conducted research reported a new laccase-producing strain-K. bupleuri G3 IBMiP. Enzyme production is induced by copper (II) ions and Tween 80 added to the medium after three days of the growth. Moreover, the positive effect of ascorbic acid on improving the quality of filtration and facilitating the purification of the enzyme by reducing the polymerization and degradation of carotenoid dyes produced by K. bupleuri, and so increasing the activity of laccase in the post-culture liquid, was demonstrated. The high activity of laccase G3 (215.4 U/L after 15 days) was obtained on a cheap substrate containing the BSG waste material. The new enzyme is characterized by cold adaptation manifested by high activity at low temperatures and low thermostability, which makes it an interesting biocatalyst in reactions carried out in cold environments. High thermolability allows for an easy inactivation of the enzyme. The potential of the enzyme in the processes of decolorization of synthetic dyes from the triphenylmethane dyes group and methylene blue belonging to heterocyclic/thiazine dyes was also reported. Further planned work on the new laccase from K. bupleuri G3 IBMiP includes the isolation and expression of the laccase-encoding gene in a heterologous host to shorten the cultivation time and increase the enzymatic activity.

It is worth emphasizing that so far, no enzymes produced by K. bupleuri yeast have been described in the literature. For the first time, this research shows the ability of these microorganisms to produce enzymes, including the cold-adapted laccase, which is extremely interesting from a biotechnological point of view.

Supplementary Materials: The following are available online at https:/ /www.mdpi.com/article/10 .3390/biom11060828/s1, Figure S1: Phylogenetic similarity of strain G3 IBMiP to other yeast strains based on the analysis of D1/D2 sequences; Figure S2: Phylogenetic similarity of strain G3 IBMiP to other yeast strains based on the analysis of ITS1 and ITS2 sequences; Table S1: Influence of inducers (at the optimal concentration) on extracellular laccase activity $(\mathrm{U} / \mathrm{L})$ during 30 days culture.

Author Contributions: Conceptualization, A.M.B. and K.M.W.; performing of experiments, K.M.W.; writing-original draft preparation, K.M.W. and A.M.B.; writing—review and editing, A.T.-C. All authors have read and agreed to the published version of the manuscript.

Funding: This research received no external funding.

Institutional Review Board Statement: Not applicable.

Informed Consent Statement: Not applicable.

Conflicts of Interest: The authors declare no conflict of interest.

\section{References}

1. Viswanath, B.; Rajesh, B.; Janardhan, A.; Kumar, A.P.; Narasimha, G. Fungal laccases and their application in bioremediation. Enzyme Res. 2014, 2014, 163242. [CrossRef] [PubMed]

2. Couto, S.R.; Herrera, J.L. Industrial and biotechnological applications of laccases: A review. Biotechnol. Adv. 2006, 24, 500-513. [CrossRef] [PubMed]

3. Rodriguez, E.; Pickard, M.A.; Vazquez-Duhalt, R. Industrial dye decolorization by laccases from ligninolytic fungi. Curr. Microbiol. 1999, 38, 27-32. [CrossRef] [PubMed] 
4. Enayatizamir, N.; Tabandeh, F.; Rodriguez-Couto, S.; Yakhchali, B.; Alikhani, H.A.; Mohammadi, L. Biodegradation pathway and detoxification of the diazo dye Reactive Black 5 by Phanerochaete Chrysosporium. Bioresour. Technol. 2011, 102, 10359-10362. [CrossRef] [PubMed]

5. Legerska, B.; Chmelova, D.; Ondrejovic, M. Degradation of synthetic dyes by laccases-A mini review. Nova Biotechnol. Chim. 2016, 15, 90-106. [CrossRef]

6. Johannes, C.; Majcherczyk, A. Natural mediators in the oxidation of polycyclic aromatic hydrocarbons by laccase mediator systems. Appl. Environ. Microbiol. 2000, 66, 524-528. [CrossRef]

7. Leelaruji, W.; Buathong, P.; Kanngan, P.; Piamtongkam, R.; Chulalaksananukul, S.; Wattayakorn, G.; Chulalaksananukul, W. Potential of laccase produced from microfungus Aureobasidium pullulans var. melanogenum to degrade polycyclic aromatic hydrocarbons. Eur. Chem. Bull. 2014, 3, 269-272.

8. Riva, S. Laccases: Blue enzymes for green chemistry. Trends Biotechnol. 2006, 24, 219-226. [CrossRef]

9. Rivera-Hoyos, C.M.; Morales-Alvarez, E.D.; Poutou-Pinales, R.A.; Pedroza-Rodriguez, A.M.; Rodriguez-Vazquez, R.; Delgado-Boada, J.M. Fungal laccases. Fungal Biol. Rev. 2013, 27, 67-82. [CrossRef]

10. Ikehata, K.; Buchanan, I.D.; Smith, D.W. Recent developments in the production of extracellular fungal peroxidases and laccases for waste treatment. J. Environ. Eng. Sci. 2004, 3, 1-19. [CrossRef]

11. Yoshida, H. Chemistry of lacquer (Urushi) part 1. J. Chem. Soc. 1883, 43, 472-486. [CrossRef]

12. Bertrand, G. Sur la presence simultanee de la laccase et de la tyrosinase dans le suc de quelques champignons. CR Hebd Seances Acad. Sci. 1896, 123, 463-465.

13. Wellington, K.W. Application of laccases in organic synthesis-A review. In Green Chemistry; Luque, R., Ed.; Nova Science Publishers, Inc.: New York, NY, USA, 2012; pp. 167-212.

14. Rovati, J.I.; Pajot, H.F.; Ruberto, L.; Mac Cormack, W.; Figueroa, L.I.C. Polyphenolic substrates and dye degradation by yasts from 25 de Mayo/King George Island (Antarctica). Yeast 2013, 30, 459-470. [CrossRef]

15. Singhal, A.; Choudhary, G.; Thakur, I.S. Characterization of laccase activity produced by Cryptococcus albidus. Prep. Biochem. Biotechnol. 2012, 42, 113-124. [CrossRef] [PubMed]

16. Wang, B.; Yan, Y.; Tian, Y.; Zhao, W.; Li, Z.; Gao, J.; Peng, R.; Yao, Q. Heterologous expression and characterization of a laccase from Colletotrichum lagenarium and decolourisation of different synthetic dyes. World J. Microbiol. Biotechnol. 2016, 32, 40. [CrossRef] [PubMed]

17. Białkowska, A.M.; Szulczewska, K.M.; Krysiak, J.; Florczak, T.; Gromek, E.; Kassassir, H.; Kur, J.; Turkiewicz, M. Genetic and biochemical characterization of yeasts isolated from Antarctic soil samples. Polar Biol. 2017, 40, 1787-1803. [CrossRef]

18. Koroljova-Skorobogat'ko, O.V.; Stepanova, E.V.; Gavrilova, V.P.; Morozova, O.V.; Lubimova, N.V.; Dzchafarova, A.N.; Jaropolov, A.I.; Makower, A. Purification and characterization of the constitutive form of laccase from the basidiomycete Coriolus hirsutus and effect of inducers on laccase synthesis. Biotechnol. Appl. Biochem. 1998, 28, 47-54. [PubMed]

19. Dhouib, A.; Hamza, M.; Zouari, H.; Mechichi, T.; Hmidi, R.; Labat, M.; Martinez, M.J.; Sayadi, S. Screening for ligninolytic enzyme production by diverse fungi from Tunisia. World J. Microbiol. Biotechnol. 2005, 21, 1415-1423. [CrossRef]

20. Sivakumar, R.; Rajendran, R.; Balakumar, C.; Tamilvendan, M. Isolation, screening and optimization of production medium for thermostable laccase production from Ganoderma sp. Int. J. Eng. Sci. Technol. 2010, 2, 7133-7141.

21. Meneses, N.G.; Martins, S.; Teixeira, J.A.; Mussatto, S.I. Influence of extraction solvents on the recovery of antioxidant phenolic compounds from brewer's spent grains. Sep. Purif. Technol. 2013, 108, 152-158. [CrossRef]

22. Laemmli, U.K. Cleavage of structural proteins during the assembly of the head of bacteriophage T4. Nature 1970, 227, 680-685. [CrossRef]

23. Bourbonnais, R.; Leech, D.; Paice, M.G. Electrochemical analysis of the interactions of laccase mediators with lignin model compounds. Biochim. Biophys. Acta 1998, 1379, 381-390. [CrossRef]

24. Pointing, S.B.; Jones, E.B.; Vrijmoed, L.L. Optimization of laccase production by Pycnoporus sanguineus in submerged liquind culture. Mycologia 2000, 92, 139-144. [CrossRef]

25. Bradford, M.M. A rapid and sensitive method for the quantitation of microgram quantities of protein utilizing the principle of protein dye binding. Anal. Biochem. 1976, 72, 248-254. [CrossRef]

26. Bills, G.F.; Menendez, V.G.; Platas, G. Kabatiella bupleuri sp. nov. (Dothideales), a pleomorphic epiphyte and endophyte of the Mediterranean plant Bupleurum gibraltarium (Apiaceae). Mycologia 2012, 104, 962-973. [CrossRef] [PubMed]

27. Peterson, S.W.; Manitchotpisit, P.; Leathers, T.D. Aureobasidium thilandense sp. nov. isolated from leaves and wooden surfaces. Int J. Syst. Evol. Microbiol. 2013, 63, 790-795. [CrossRef]

28. Chakroun, H.; Mechichi, T.; Martinez, M.J.; Dhouib, A.; Sayadi, S. Purification and characterization of a novel laccase from the ascomycete Trichoderma atroviride: Application on bioremediation of phenolic compounds. Process Biochem. 2010, 45, 507-513. [CrossRef]

29. Sun, K.; Cheng, X.; Yu, J.; Chen, L.; Wei, J.; Chen, W.; Wang, J.; Li, S.; Liu, Q.; Si, Y. Isolation of Trametes hirsuta La-7 with high laccase-productivity and its application in metabolism of 17 $\beta$-estradiol. Environ. Pollut. 2020, 263, 114381. [CrossRef]

30. Klonowska, A.; Le Petit, J.; Tron, T. Enhancement of minor laccases production in the basidiomycete Marasmius quercophilus C30. FEMS Microbiol. Lett. 2001, 200, 25-30. [CrossRef]

31. Chen, S.; Ge, W.; Buswell, J.A. Biochemical and molecular characterization of a laccase from the edible straw mushroom, Volvariella volvacea. Eur. J. Biochem. 2004, 271, 318-328. [CrossRef] 
32. Wang, Z.; Cai, Y.; Liao, X.; Zhang, F.; Zhang, D.; Li, Z. Production and characterization of a novel laccase with cold adaptation and high thermal stability from an isolated fungus. Appl. Biochem. Biotechnol. 2010, 162, 280-294. [CrossRef]

33. Cambria, M.T.; Ragusa, S.; Calabrese, V.; Cambria, A. Enhanced laccase production in white-rot fungus Rigidoporus lignosus by the addition of selected phenolic and aromatic compounds. Appl. Biochem. Biotechnol. 2011, 163, 415-422. [CrossRef]

34. Dhillon, G.S.; Kaur, S.; Brar, S.K. In-vitro decolorization of recalcitrant dyes through an ecofriendly approach using laccase from Trametes versicolor grown on brewer's spent grain. Int. Biodeterior.Biodegrad. 2012, 72, 67-75. [CrossRef]

35. Daassi, D.; Zouari-Mechichi, H.; Prieto, A.; Martinez, M.J.; Nasri, M.; Mechichi, T. Purification and biochemical characterization of a new alkali-stable laccase from Trametes sp. isolated in Tunisia: Role of the enzyme in olive mill waste water treatment. World J. Microbiol. Biotechnol. 2013, 29, 2145-2155. [CrossRef] [PubMed]

36. Gonzales, J.C.; Medina, S.C.; Rodriguez, A.; Osma, J.F.; Almeciga-Diaz, C.J.; Sanchez, O.F. Production of Trametes pubescens laccase under submerged and semi-solid culture conditions on agro-industrial wastes. PLoS ONE 2013, 8, e73721. [CrossRef]

37. Guo, L.Q.; Lin, S.X.; Zheng, X.B.; Huang, Z.R.; Lin, J.F. Production, purification and characterization of a thermostable laccase from a tropical white-rot fungus. World J. Microbiol. Biotechnol. 2011, 27, 721-735. [CrossRef]

38. Galhaup, C.; Haltrich, D. Enhanced formation of laccase activity by the white-rot fungus Trametes pubescens in the present of copper. Appl. Microbiol. Biotechnol. 2001, 56, 225-232. [CrossRef] [PubMed]

39. Demkiv, O.M.; Gayda, G.Z.; Broda, D.; Gonchar, M.V. Extracellular laccase from Monilinia fructicola: Isolation, primary characterization and application. Cell Biol. Int. 2021, 45, 536-548. [CrossRef]

40. Kruszewska, J.; Palamarczyk, G.; Kubicek, C.P. Stimulation of exoprotein secretion by choline and Tween 80 in Trichoderma reesei QM 9414 correlates with infcreased activities of dolichol phosphate mannose synthase. J. Gen. Microbiol. 1990, 136, 1293-1298. [CrossRef]

41. Calado, C.R.; Brandao, M.; Biscaia, J.; Cabral, J.M.; Fonseca, L.P. Effect of Tween 80 on stability and secretion of hydrophobic tagged-cutinases. Chem. Biochem. Eng. Q. 2009, 23, 411-417. [CrossRef]

42. Kiiskinen, L.L.; Ratto, M.; Kruus, K. Screening for novel laccase-producing microbes. J. Appl. Microbiol. 2004, 97, 640-646. [CrossRef] [PubMed]

43. Lomascolo, A.; Cayol, J.L.; Roche, M.; Guo, L.; Robert, J.L.; Record, E.; Lesage-Meessen, L.; Ollivier, B.; Sigoillot, J.C.; Asther, M Molecular clustering of Pycnoporus strain from various geographic origins and isolation of monokaryotic strains for laccase hyperproduction. Mycol. Res. 2002, 106, 1193-1203. [CrossRef]

44. Dekker, R.F.; Barbosa, A.M. The effects of aeration and veratryl alcohol on the production of two laccases by the ascomycete Botryosphaeria sp. Enzyme Microb. Technol. 2001, 28, 81-88. [CrossRef]

45. Da Cunha, M.A.A.; Barbosa, A.M.; Giese, E.C.; Dekker, R.F. The effect of carbohydrate carbon sources on the production of constitutive and inducible laccases by Botryosphaeria sp. J. Basic Microbiol. 2003, 43, 385-392. [CrossRef]

46. Arora, D.S.; Gill, P.K. Effects of media and supplements on laccase production by some white rot fungi. Bioresour. Technol. 2001, 77, 89-91. [CrossRef]

47. Jafari, N.; Rezaie, D.; Rezaei, R.; Dilmaghani, H.; Khoshayand, M.R.; Faramarzi, M.A. Improved production and characterization of a highly stable laccase from the halophilic bacterium Chromohalobacter salexigens for the efficient delignification of almond shell bio-waste. Int. J. Biol. Macromol. 2017, 105, 489-498. [CrossRef] [PubMed]

48. Gorbatova, O.N.; Koroleva, O.V.; Landesman, E.O.; Stepanova, E.V.; Zherdev, A.V. Increase of the detoxification potential of basidiomycetes by induction of laccase biosynthesis. Appl. Biochem. Microbiol. 2006, 42, 414-419. [CrossRef]

49. Dhawan, S.; Lal, R.; Kuhad, R.C. Ethidium bromide stimulated hyper laccase production from bird's nest fungus Cyanthus bulleri. Lett. Appl. Microbiol. 2002, 36, 64-67. [CrossRef] [PubMed]

50. Pazarlog ${ }^{\natural}$ lu, N.K.; Sariis ik, M.; Telefoncu, A. Laccase: Production by Trametes versicolor and application to denim washing. Process Biochem. 2005, 40, 1673-1678. [CrossRef]

51. Rich, J.O.; Manitchotpisit, P.; Peterson, S.W.; Leathers, T.D. Laccase production by diverse phylogenetic clades of Aureobasidium pullulans. RJAS 2011, 1, 41-47.

52. Rich, J.O.; Leathers, T.D.; Anderson, A.M.; Bischoff, K.M.; Manitchotpisit, P. Laccases from Aureobasidium pullulans. Enzyme Microb. Technol. 2013, 53, 33-37. [CrossRef] [PubMed]

53. Lo, S.C.; Ho, Y.S.; Buswell, J.A. Effect of phenolic monomers on the production of laccases by the edible mushroom Pleurotus sajo-caju, and partial characterization of a major laccase component. Mycologia 2001, 93, 421-431. [CrossRef]

54. Linden, R.M.; Schilling, B.C.; Germann, U.A.; Lerch, K. Regulation of laccase synthesis in induced Neurospora crassa cultures. Curr. Genet. 1991, 19, 375-381. [CrossRef] [PubMed]

55. Lee, I.Y.; Jung, K.H.; Lee, C.H.; Park, Y.H. Enhanced production of laccase in Trametes versicolor by the addition of ethanol. Biotechnol. Lett. 1999, 21, 965-968. [CrossRef]

56. Dekker, R.F.; Vasconcelos, A.F.; Barbosa, A.M.; Giese, E.C.; Paccola-Meirelles, L. A new role for veratryl alcohol: Regulation of synthesis of lignocellulose-degrading enzymes in the ligninolytic ascomyceteous fungus, Botryosphaeria sp.; influence of carbon source. Biotechnol. Lett. 2001, 23, 1987-1993. [CrossRef]

57. Lomascolo, A.; Record, E.; Herpoel-Gimbert, I.; Delattre, M.; Robert, J.L.; Georis, J.; Dauvrin, T.; Sigoillot, J.C.; Asther, M. Overproduction of laccase by a monokaryotic strain of Pycnoporus cinnabarinus using ethanol as inducer. J. Appl. Microbiol. 2003, 94, 618-624. [CrossRef] 
58. Dhakar, K.; Pandey, A. Laccase production from a temperature and $\mathrm{pH}$ tolerant fungal strain of Trametes hirsuta (MTCC 11397). Enzyme Res. 2013, 2013, 869062. [CrossRef]

59. Mougin, C.; Kollmann, A.; Jolivalt, C. Enhanced production of laccase in the fungus Trametes versicolor by the addition of xenobiotics. Biotechnol. Lett. 2002, 24, 139-142. [CrossRef]

60. Froehner, S.C.; Eriksson, K.E. Induction of Neurospora crassa laccase with protein synthesis inhibitors. J. Bacteriol. 1974, 120, 450-457. [CrossRef] [PubMed]

61. Sethuraman, A.; Akin, D.E.; Eriksson, K.E. Production of ligninolytic enzymes and synthetic lignin mineralization by the bird's nest fungus Cyathus stercoreus. App. Microbiol. Biotechnol. 1999, 52, 689-697. [CrossRef] [PubMed]

62. Thurston, C.F. The structure and function of fungal laccases. Microbiology 1994, 140, 13-26. [CrossRef]

63. Klaui, H.; Bauernfeind, J.C. Carotenoids as food color. In Carotenoids as Colorants and Vitamin A Precursors; Bauernfeind, J.C., Ed.; Academic Press: New York, NY, USA, 1981; pp. 48-319.

64. Gassara, F.; Ajila, C.M.; Brar, S.K.; Tyagi, R.D.; Verma, M.; Valero, J. Influence of aeration and agitation modes on solid-state fermentation of apple pomace waste by Phanerochaete chrysosporium to produce ligninolytic enzymes and co-extract polyphenols Int. J. Food Sci. Technol. 2013, 48, 2119-2126. [CrossRef]

65. Dhillon, G.S.; Brar, S.K.; Kaur, S.; Metahni, S.; M'hamdi, N. Lactoserum as a moistening medium and crude inducer for fungal cellulase and hemicellulase induction through solid-state fermentation of apple pomace. Biomass Bioenergy 2012, 41, 165-174. [CrossRef]

66. Dhillon, G.S.; Kaur, S.; Brar, S.K.; Gassara, F.; Verma, M. Improved xylanase production using apple pomace waste by Aspergillus niger in koji fermentation. Eng. Life Sci. 2012, 12, 198-208. [CrossRef]

67. Tepe, O.; Dursun, A.Y. Exo-pectinase production by Bacillus pumilus using different agricultural wastes and optimizing of medium components using response surface methodology. Environ. Sci. Pollut. Res. 2014, 21, 9911-9920. [CrossRef]

68. Dhillon, G.S.; Brar, S.K.; Valero, J.R. Bioproduction of hydrolytic enzymes using apple pomace waste by A. niger: Application in biocontrol formulations and hydrolysis of chitin/chitosan. Bioprocess Biosyst. Eng. 2011, 34, 1017-1026. [CrossRef]

69. Kaur, S.; Dhillon, G.S.; Brar, S.K.; Chauhan, V.B. Carbohydrate degrading enzyme production by plant pathogenic mycelia and microsclerotia isolates of Macrophomina phaseolina through koji fermentation. Ind. Crops Prod. 2012, 36, 140-148. [CrossRef]

70. Freixo do Rosario, M.; Karmali, A.; Frazão, C.; Arteiro, J.M. Production of laccase and xylanase from Coriolus versicolor grown on tomato pomace and their chromatographic behaviour on immobilized metal chelates. Process Biochem. 2008, 43, 1265-1274. [CrossRef]

71. Pan, K.; Zhao, N.; Yin, Q.; Zhang, T.; Xu, X.; Fang, W.; Hong, Y.; Fang, Z.; Xiao, Y. Induction of a laccase Lcc9 from Coprinopsis cinerea by fungal coculture and its application on indigo dye decolorization. Bioresour. Technol. 2014, 162, 45-52. [CrossRef]

72. Yang, J.; Lin, Q.; Ng, T.B.; Ye, X.; Lin, J. Purification and characterization of a novel laccase from Cerrena sp. HYB07 with dye decolorizing ability. PLOS ONE 2014, 9, e110834. [CrossRef]

73. Mtibaà, R.; de Eugenio, L.; Ghariani, B.; Louati, I.; Belbahri, L.; Nasri, M.; Mechichi, T. A halotolerant laccase from Chaetomium strain isolated from desert soil and its ability for dye decolourization. 3 Biotech 2017, 7, 329. [CrossRef]

74. Mtibaà, R.; Barriuso, J.; de Eugenio, L.; Aranda, E.; Belbahri, L.; Nasri, M.; Martínez, M.J.; Mechichi, T. Purification and characterization of a fungal laccase from the ascomycete Thielavia sp. and its role in the decolorization of a recalcitrant dye. Int. J. Biol. Macromol. 2018, 120, 1744-1751. [CrossRef]

75. Aung, T.; Jiang, H.; Chen, C.C.; Liu, G.L.; Hu, Z.; Chi, Z.M.; Chi, Z. Production, gene cloning and overexpression of a laccase in the marine-derived yeast Aureobasidium melanogenum strain 11-1 and characterization of the recombinant laccase. Mar. Biotechnol. 2019, 21, 76-87. [CrossRef] [PubMed]

76. Ko, E.M.; Leem, Y.E.; Choi, H.T. Purification and characterization of laccase isozymes from white-rot basidiomycete Ganoderma lucidum. Appl. Microbiol. Biotechnol. 2001, 58, 98-102. [CrossRef]

77. Kiiskinen, L.L.; Viikari, L.; Kruus, K. Purification and characterization of a novel laccase from the ascomycete Melanocarpus albomyces. Appl. Microbiol. Biotechnol. 2002, 59, 198-204. [CrossRef] [PubMed]

78. Yang, Y.; Ding, Y.; Liao, X.; Cai, Y. Purification and characterization of a new laccase from Shiraia sp. SUPER-H168. Process Biochem. 2013, 48, 351-357. [CrossRef]

79. Moturi, B.; Singara Charya, M.A. Decolourisation of crystl violet and malachite green by fungi. Sci. World J. 2009, 4, 28-33. [CrossRef]

80. Kumar, M.; Mishra, A.; Singh, S.S.; Srivastava, S.; Thakur, I.S. Expression and characterization of novel laccase gene from Pandoraea sp. ISTKB and its application. Int. J. Biol. Macromol. 2018, 115, 308-316. [CrossRef]

81. Zheng, F.; Cui, B.K.; Wu, X.J.; Meng, G.; Liu, H.X.; Si, J. Immobilization of laccase onto chitosan beads to enhance its capability to degrade synthetic dyes. Int. Biodeterior. Biodegrad. 2016, 110, 69-78. [CrossRef]

82. Guo, X.; Zhou, S.; Wang, Y.; Song, J.; Wang, H.; Kong, D.; Zhu, J.; Dong, W.; He, M.; Hu, G.; et al. Characterization of highly thermostable and organic solvent-tolerant copper-containing polyphenol oxidase with dye-decolorizing ability from Kurthia huakuii LAM0618. PLoS ONE 2016, 11, e0164810. [CrossRef]

83. Forooranfar, H.; Moezzi, A.; Agheie-Khozani, M.; Mahmoudjanlou, Y.; Ameri, A.; Niknejad, F.; Faramarzi, M.A. Synthetic dye decolorization by three sources of fungal laccase. Iran. J. Environ. Health Sci. Eng. 2012, 9, 27. [CrossRef] [PubMed]

84. Ademakinwa, A.N.; Agboola, F.K. Bioremediation of textile dye solutions, textile dye mixtures and textile effluents by laccase from Aureobasidium pullulans (de Bary) G. Arnaud (1918) (Fungi: Ascomycota). Braz. J. Biol. Sci. 2015, 2, $253-262$. 